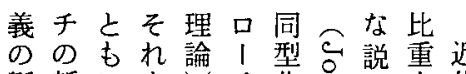

誕新にを化寺明を代

生し、効でを論るが占社

とさそ率あ整し占なめ会

展亡の气り理を它さるは

開有欠統、寸学㫼れの雇

に効陷制そる歴を和用

つ性がにれた主をてっや

いを明分をめ義朵たる地

て示ら類社にのイた。問位

のしかし会ふ説才しに達

経てにて化た明三しに成

験いさいとつ理アかつに

的和る配の論之しいお

研。る。分前とし!

究最。こに提 $\mathrm{L} 、$ 本はて

の後その分って代論技学

方にのふ類メ読・表は僟歴

问こあたし夕み.者こ機が

とうとうて理直尤れ熋大

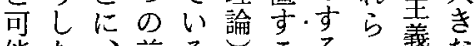

能た、前る、るの我な

性制学提。少と制伝人規

に度校をもらが度統的定

つ論效組 5 考重論的資力

い的果みひ察要派了的算を

$\tau ア と$ 合としとの

(若プ雇わつてい教㗪つ

キ芉口用せはいう教只不学

|の|のる、る指育、ク歴

ワ提千理こ雇。摘論チリ社

1言を論と用ひをしに|会

ドを導にににとおお大たこで

.. おきつよつつこ制きンあ

学このいっいはな度なグる

歴な系ててて学っと矢理。

つ異複の校てし陷論で

制てしな数前効いてが、は

度いなつの提果るのあ訓

論るがた伝㞋に。教り練な

的○ら前統学つそ䘚、費ぜ

$ア$ 、提的歴いこ論む用学

日をなのてでしし理歴

本お説需のまとろ諭が

社く明要前ず $\neg$ 、地

会制理 の提複組 $シ ゙$ 葛位

に度論理乞数織 ヨ藤達

方論を論学の論ン理成

け的整歴伝し・論に

るア理での統っマなお

学プすあ供的制イどお

歴口るり給了度ヤ様き

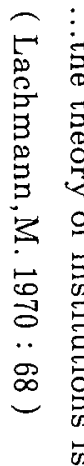

学

. 楚

伝 社

的 会

論

客

0
0
0
0
0
0
0
0
0
0

再

手考

之

度

論

的

ア

現
社
念
学
研
究
第
卷
巻

内

杂

洋 
の 理 が達

前しな成近

提たさに代

理いれ杂社

論学き歴た規雇

で社。定用

あ会こ力や

るのれを地

。説ら导位

$う$ 理 説の书

ひ論明だに

之は理ろ拉

はふを市て

た統 。学

学 つ一人歴

歴 の 的的 が

が前に資大

需提見本き

要に渡論な

さかそや規

扎方不定

るわ。方

雇つそlを

用てのりも

にいた二

つるめ 学

い○にグ 磨

てひ理 社

$の 亡$ 説 論 会

前つ明あで

提は理るあ

理糜 論いる

論を前葛で

で供提藤は

あす年論な

るる夕なぜ

学理 よ゙学

校 論さ歴

効 まが

果にざ雇

によま用

つつなや

认て 説 地

て整明位
唆口ド説こ要子制 ジ

に1・明亡の度妇ア

$つ チ ア$ 理に理一論ンメ

いのプ論あ論九的: リ

て新口でるし九アマ方力

考し! あ。さきプイで

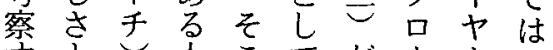

すと金こてが、标

る有を的で読、手九尽

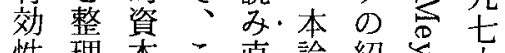

性理本こ直. 論紹志士

をし理 の 守. 文介心年

検、論可このは巳代

討つや学之貝わ的がをか

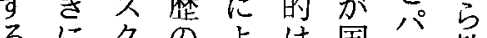

る同１供少然国イ教

最じリ給て制も才充 後作三の 、度な組

に業 ン理 学論さ制を織

制を グ 論 歴派 れ

論度論と会 いいるる

的論な江教る制い

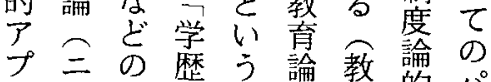

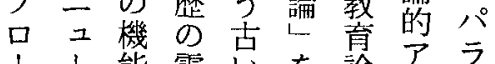

11 能需いを調 ア゚ ダ

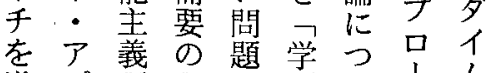

導 プ理理へ歴い! 公

き口論論の些てチ転

の 1 品新供は今換

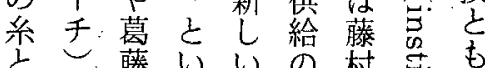

$亡 \smile$ 藤 $心 W の$ 村 $\underset{\Xi}{\Xi}$

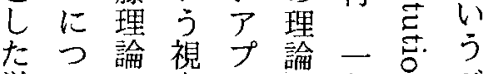

学いの点口憵九今心

歴て伝架! 公总き

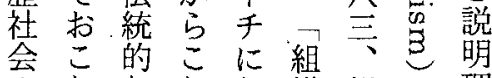

のななれな織組理

経い説まる論織さ論

験、明でこし論がが

的制理のとをにこあ

研度論学を䒚つれら

究論へ歴指学いでわ

へ的才社摘歴て あ れ

示プル 会守需金る。
は 
社モ - 性 心 り 歴の層そ い歴処た前効理と

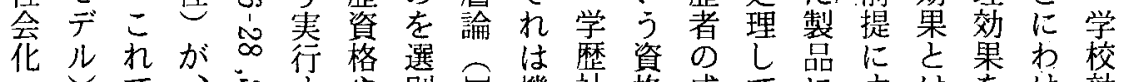
-乙で、踦や別可機社格成てにすは效

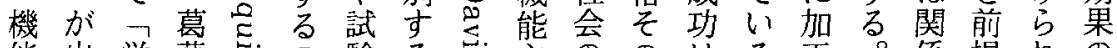

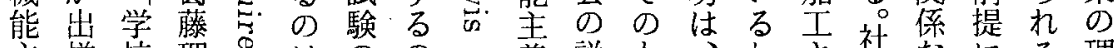
主揃 校理

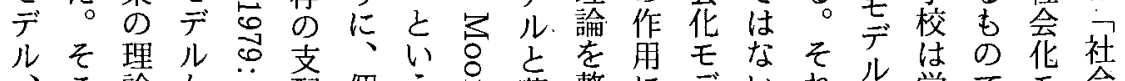

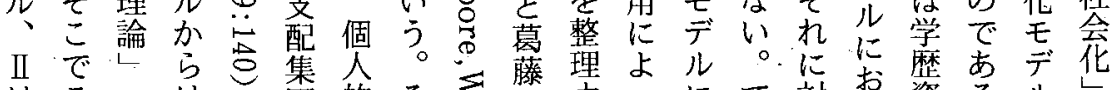

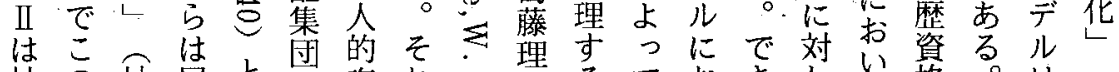
社の社属 䎡で恣れ 会三会性考 あ 意 - の毛義るかはしにルのささは配学出に知导

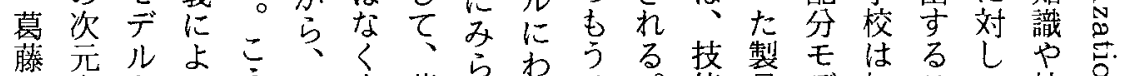

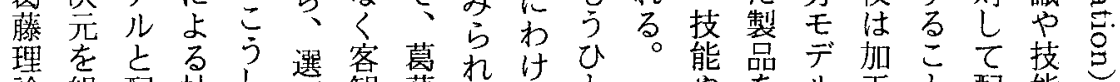

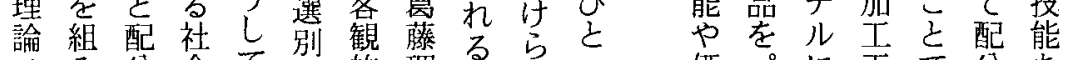

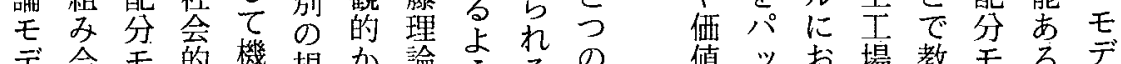
デ合モ的機規か論 うる れ

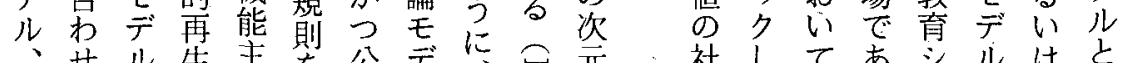

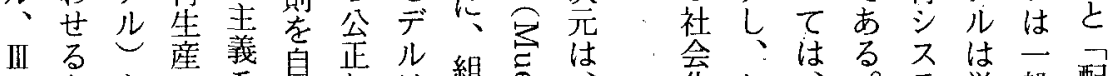

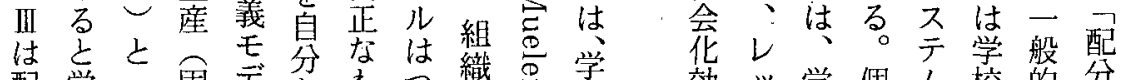

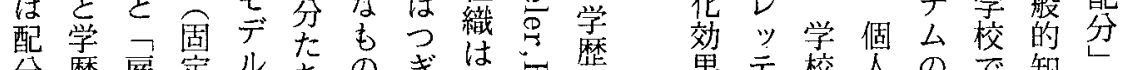

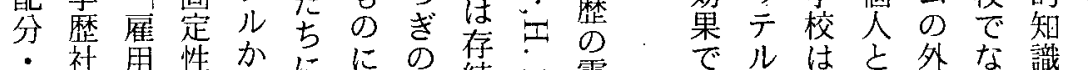

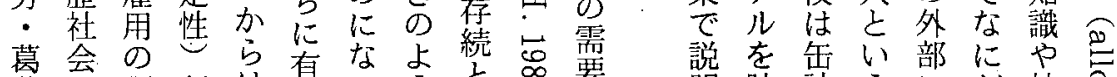

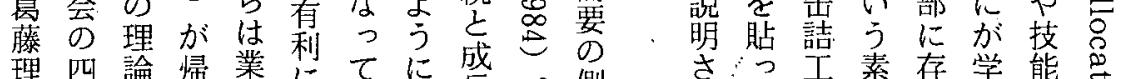

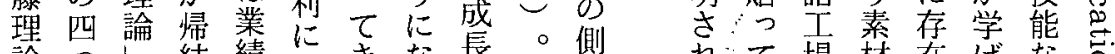

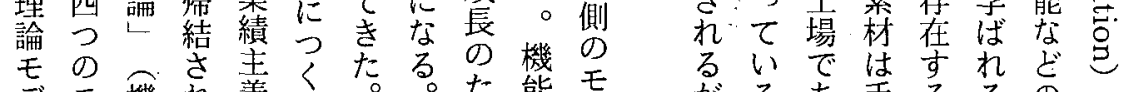

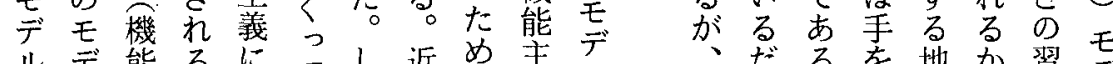

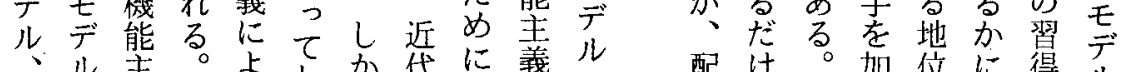

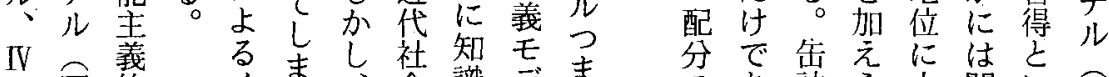

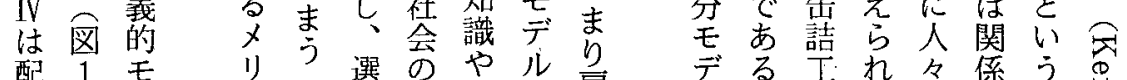

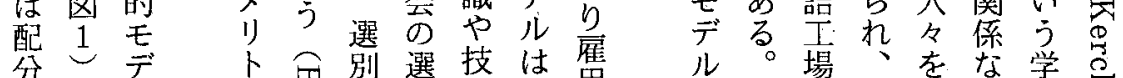

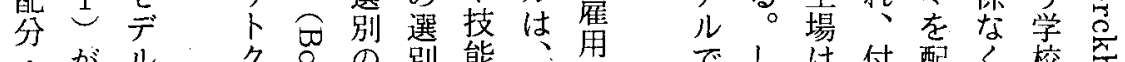

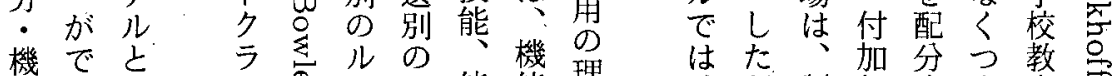
機で

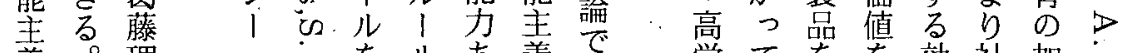

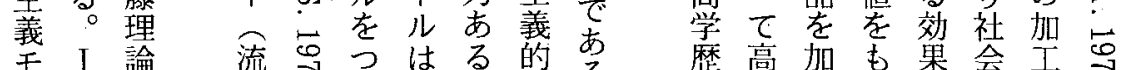

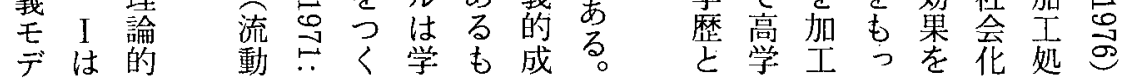




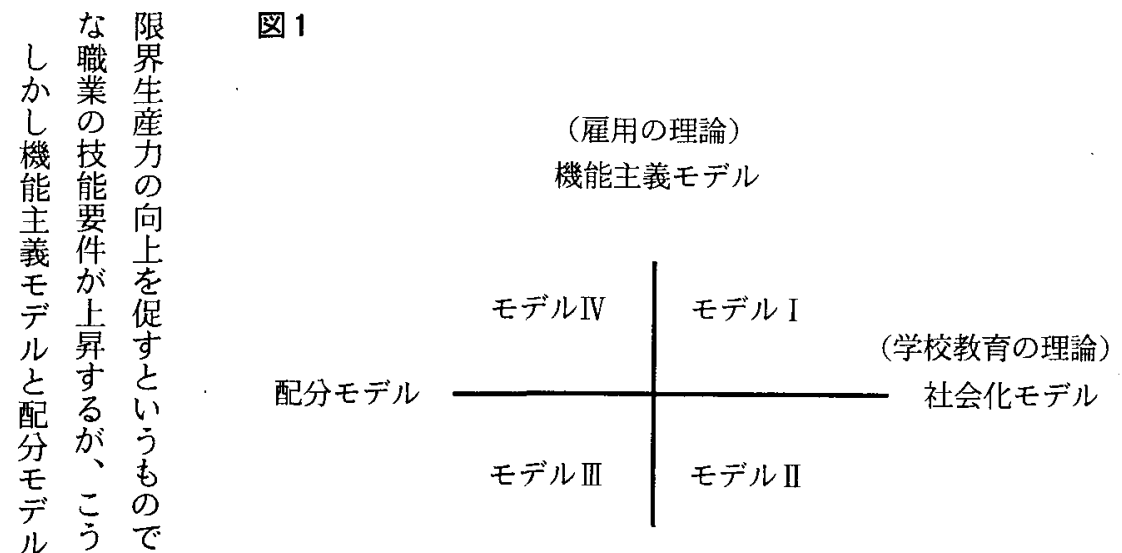

葛藤理論モデル

組たり

合能技

わや術

せ 知 機

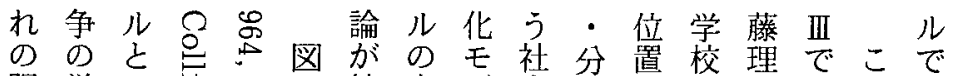

モ

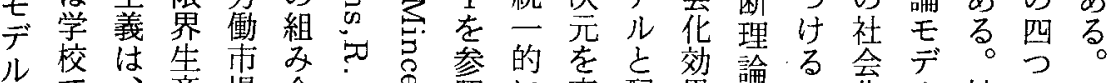

IV 学産場合邦嵒照に交配果論こ充儿社の

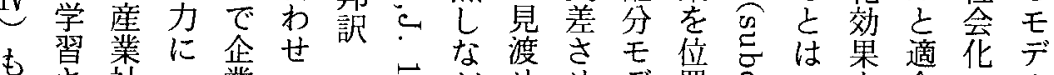

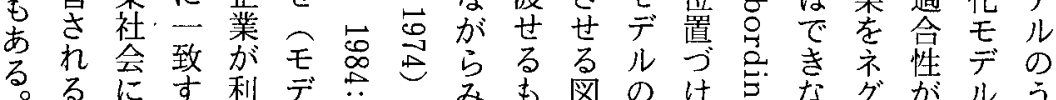

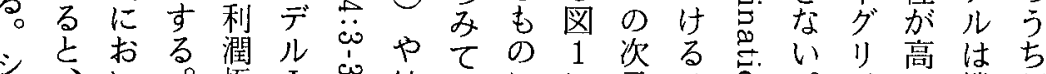

グ、い。極 I 岁技いにに元气宫。济い機理

ナとてそ夲し術こなよにと名まブか能解

ルいはし华では機うる。う機が写だら主し

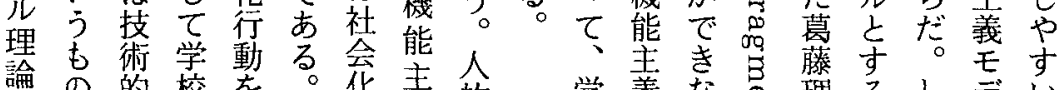

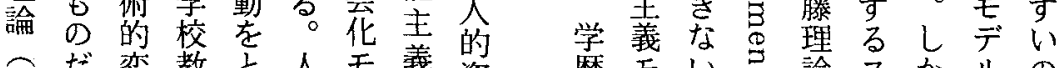

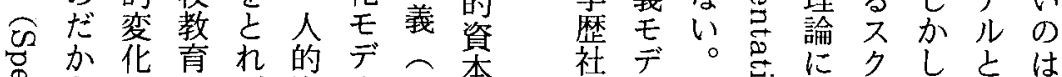

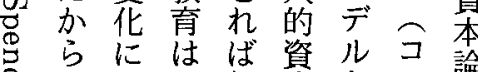

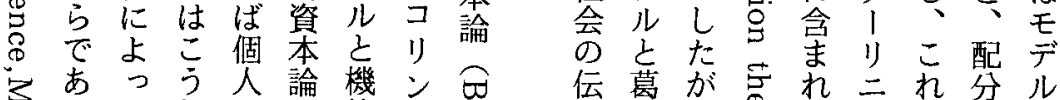

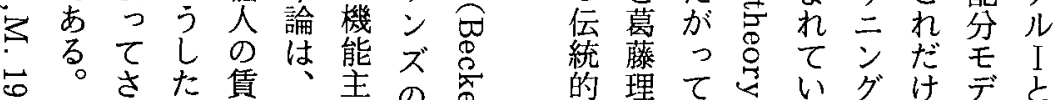

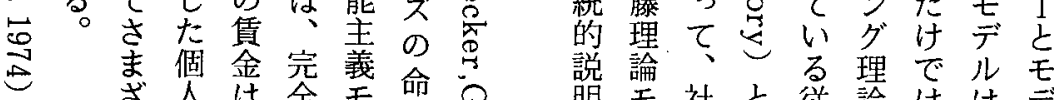

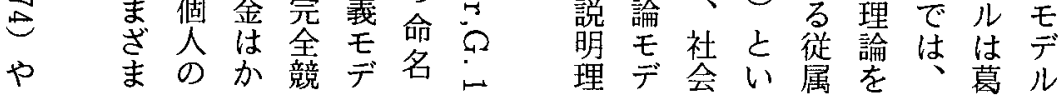


がを嗐はし・ぎお義態莫学ていど配すいにこフ

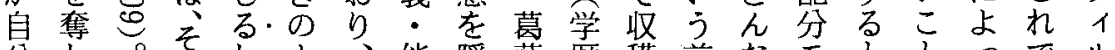

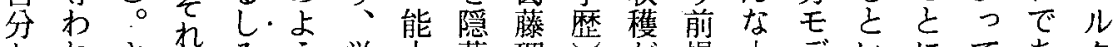
たれさ老みう学力蔽理势提土デいにてあ夕 ちすら設たに歴主高論さふに地ルうな習る!

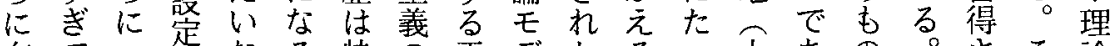

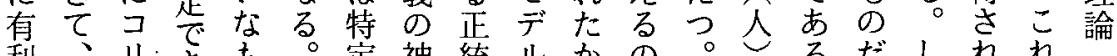

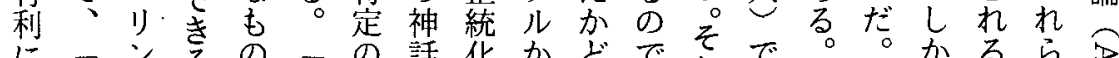
に学当の゙教の話化からでれで。。かるらる

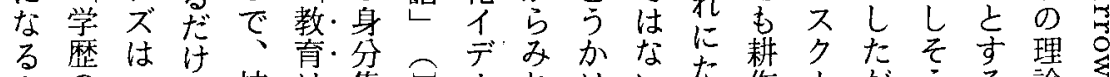

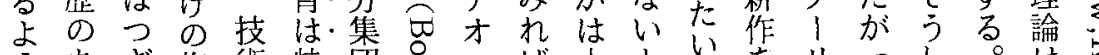

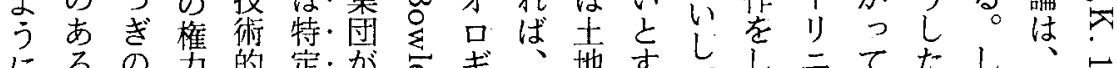

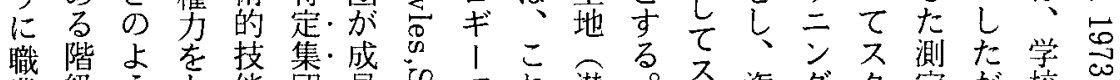

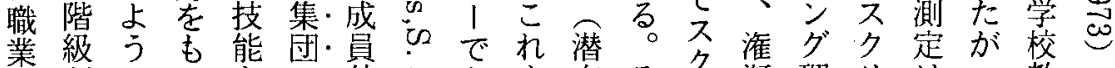

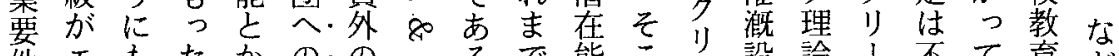

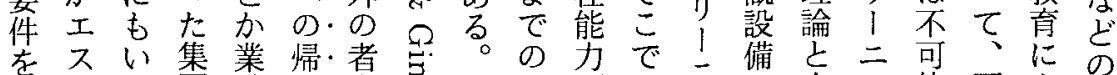

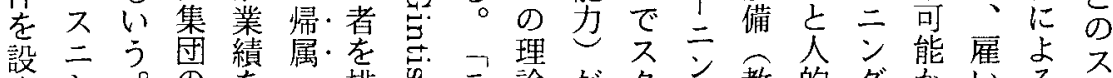

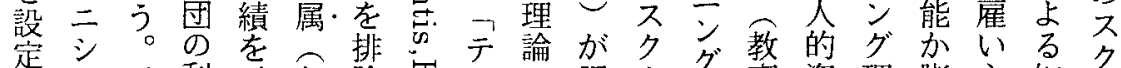

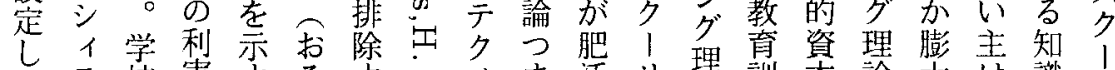

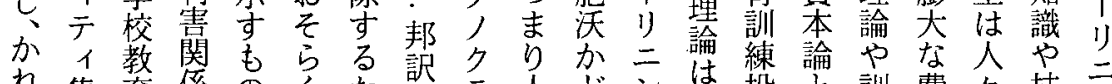

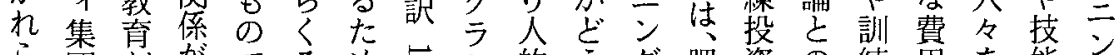
ら団ががでそめ怘シ的うグ萌資の練角を能グ

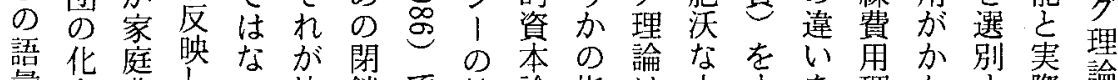

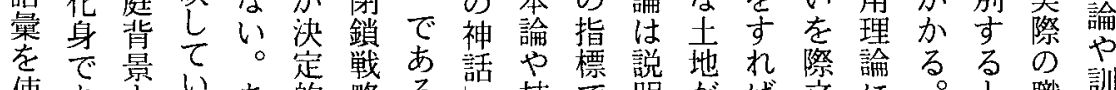

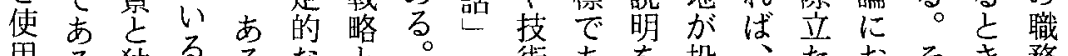

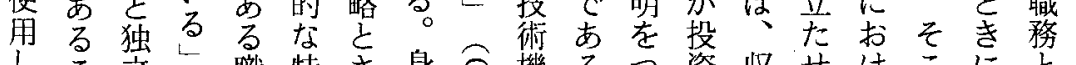
しこ立乞職特さ身令機るう資収せけこに費 な上に傍業徵机分名能き老穫れるで潜は用 いに社点にとる集吉主との生がば学学在無理 も注会引どなか団義。よむふつ校歴能関論

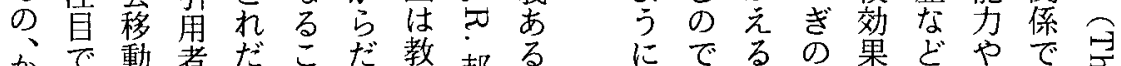

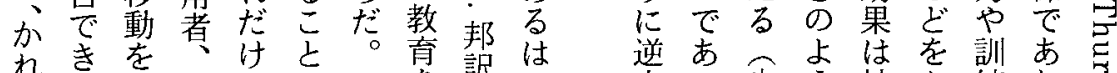

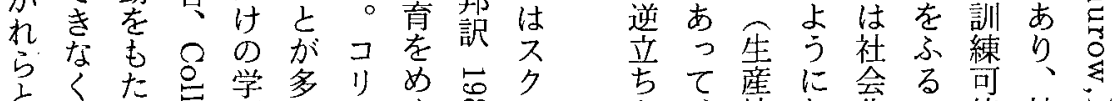

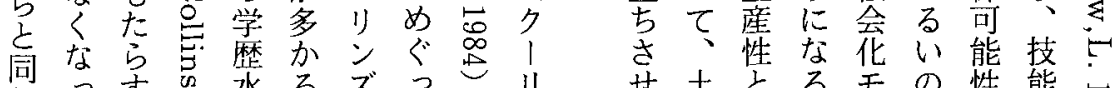

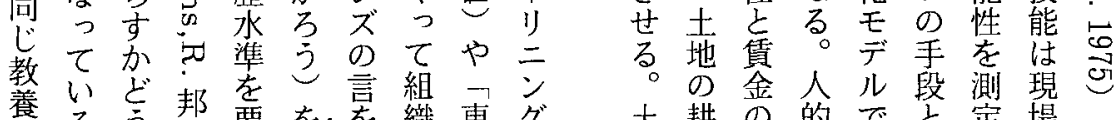

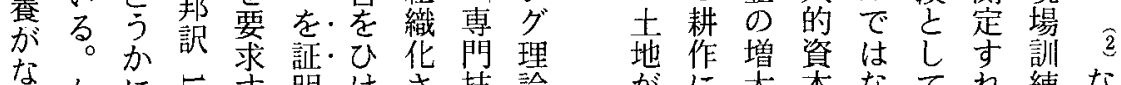

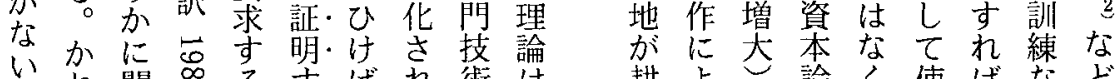
者热関怘る 
の個れか階・ぎ

基人てら層.の 亡 資 る てが、本の・述てと要労自働分最論論葛る。 差こ 声解へベい求働発市断初し帮吕藤と理

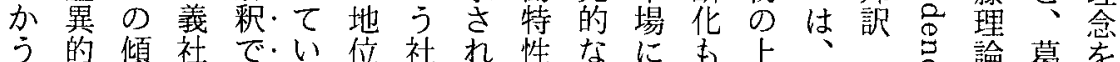

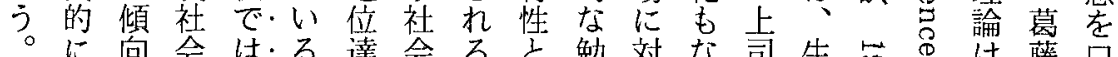

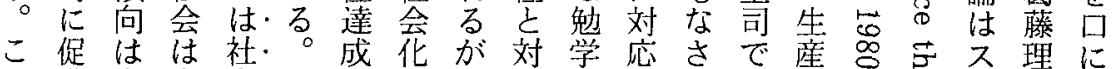

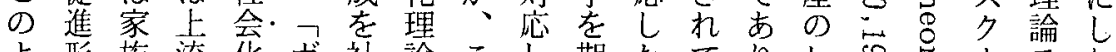

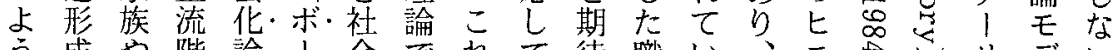

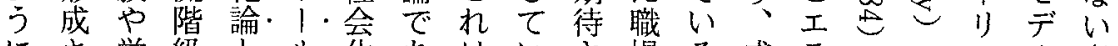

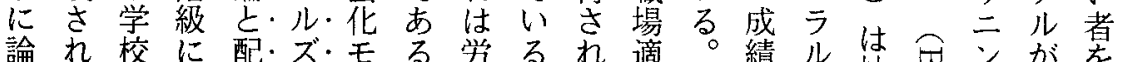

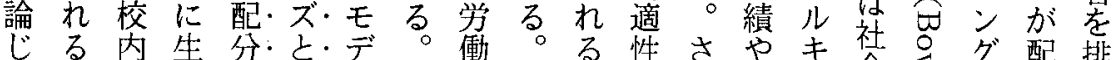

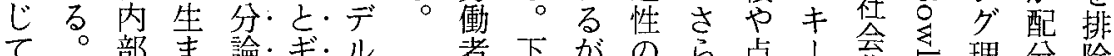

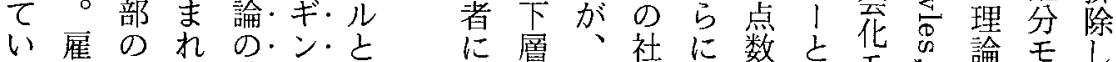

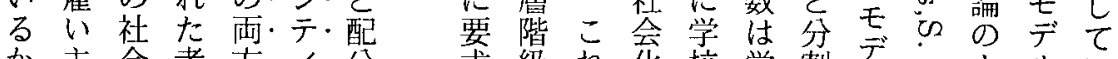

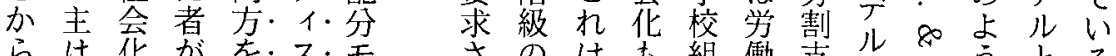

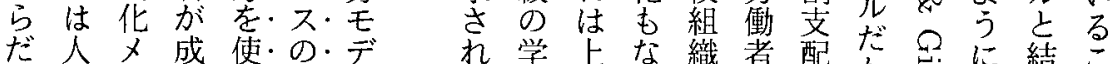

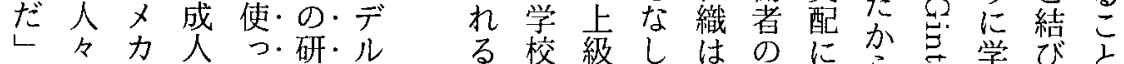

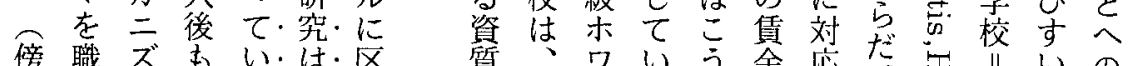

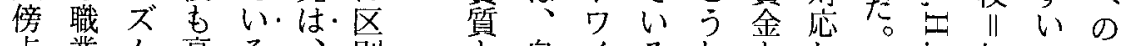

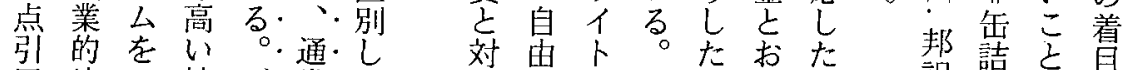
用地つ社ボ常たた店度力中職な社訳詰と

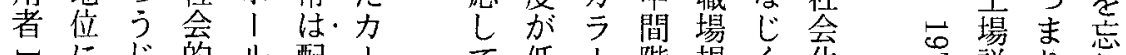

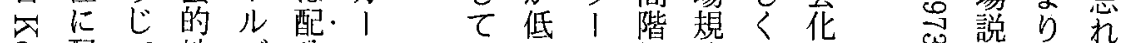
配て 地 ズ分・ 分求 位 と論・ フ 寄皇

$\vec{b}$ 際て 得

?に心守イれ・の

它そる。傾は否・文

心いまをぎ䒠・注

అ

。差出むよかな 異身ようれ。市 的階うにら・で 資級に論は・周 質に組じ織て 教. 選つ化い䏍. 主 別てさると.つ

いくが級律外 が る指資やの生学 対示本家流会叝組 応れの 階玄酬織 理た目級にでで 論こ的のとあな 学や生占るさ 学を価徒ま。れ 校や值たら学て 效りを古索校心

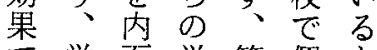
で学面学第個と 及校化校 一人、 机のしは次化う ば規て、労さ理 則自自働 れ論 従に発由市たで 属応的度場競
心 説

怘は や W III つ や。にて リボない 1 るる ズルさ こ の上が是 身ギわ占 分之市怘 文厅方品 化 1 品 の ス 伝 $の$ ज 達対每 乞 原 
れた会I 効藤い学従識文不华吉大コ るモ。充の果理そ校属や化しはさ非る事りコ

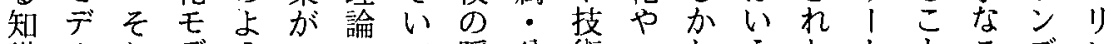

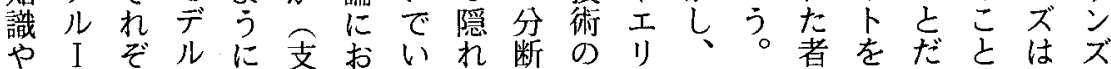

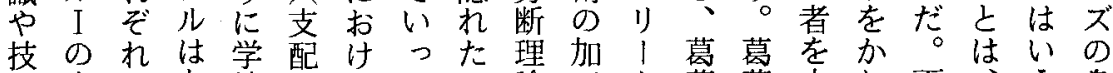
能人のあ校集るて力論工卜藤藤中れ下方方身 の的問くの団学お少や製身理理 $\dot{二}$ 級上学分 ほ資題ま独に校かキ身品分論論下学䌡校齐 上本点で自よの和工分工文の家級同校学侪华 ん論に従のつ社ばラ文場化いで職じは校力の

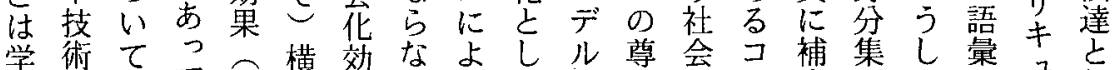

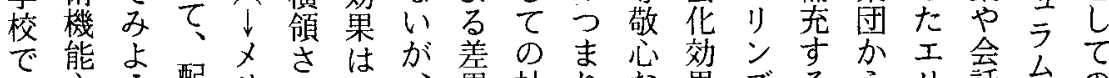

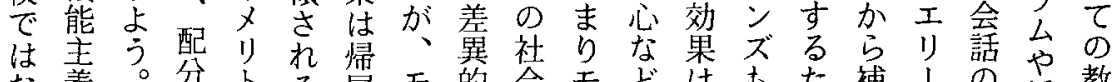

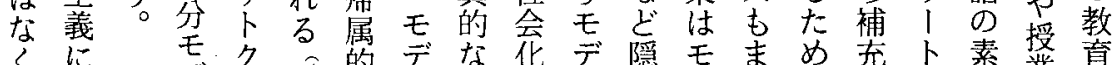

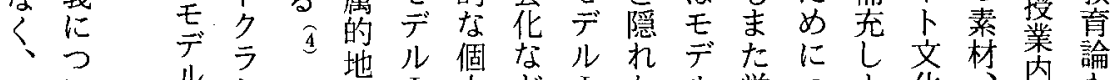

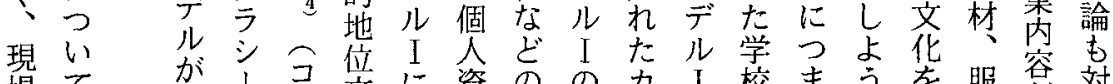

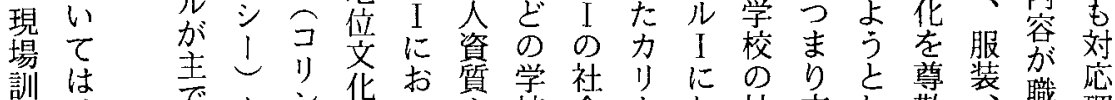

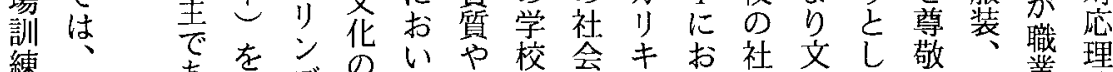

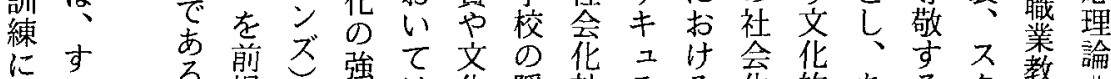

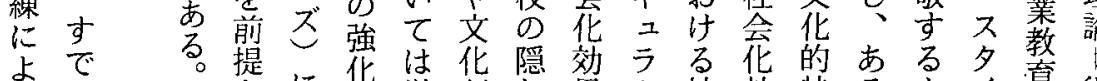
に华は化隠效亏る货的ある多教

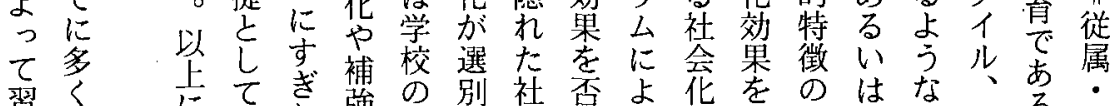

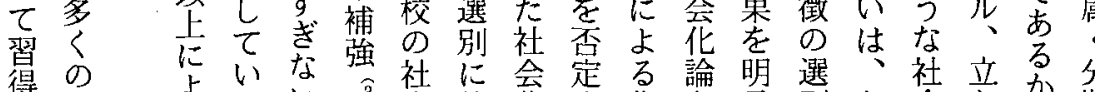
さ惩多るるい:

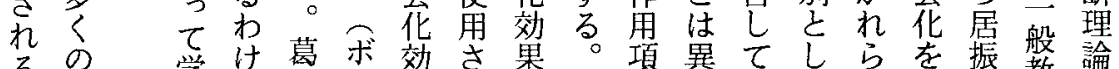

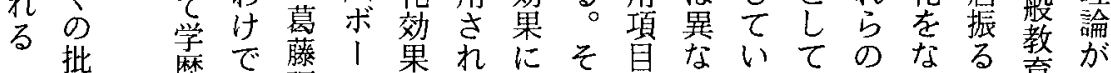

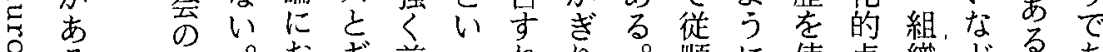

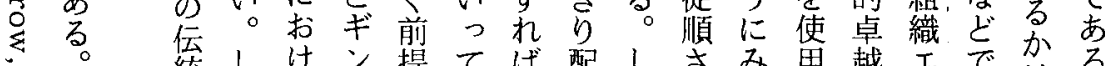

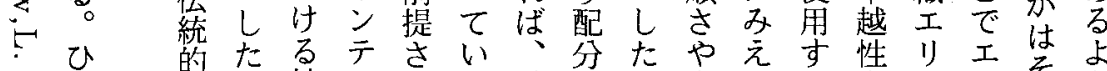

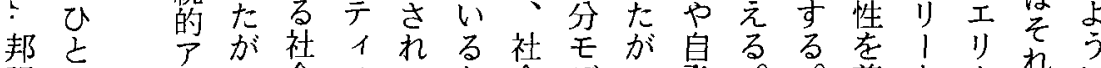
訳つプつ会不てか会デつ発。㥢卜!㨟に

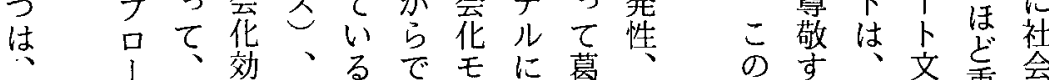

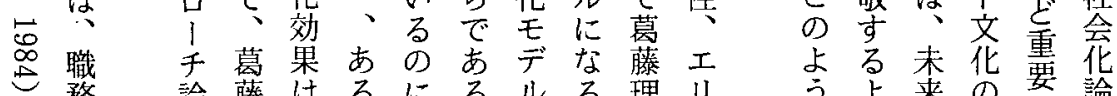

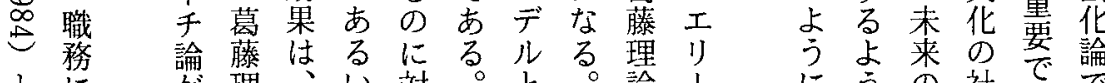
とにが理、い対。と。論|にうの社でで

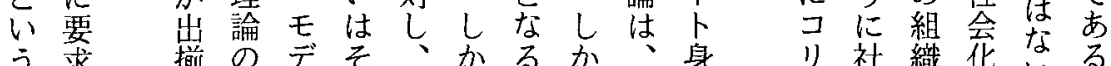

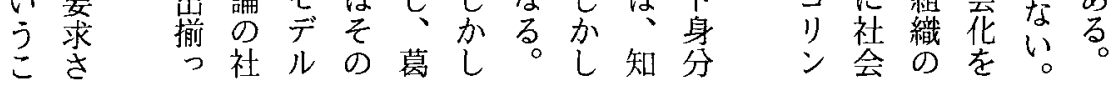




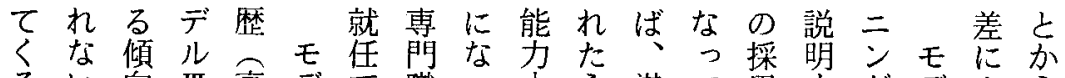
藤るい向 III 高デで職う水ら潜て用卞グデょら 理。卞の卒ルきのて準す在学行る理ルるの 論吕要杰な場しをぐ能校動。論 I も批

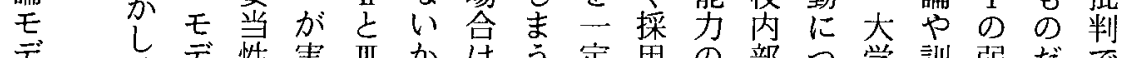
デ維実吕尔はう定用の部つ学訓弱だで ル組ルをはでら説。にし識でいで練点てあ に 織 II 示しあだ朚モ保て別のて何費を宙る

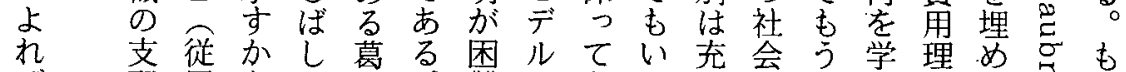

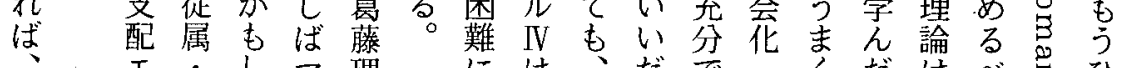

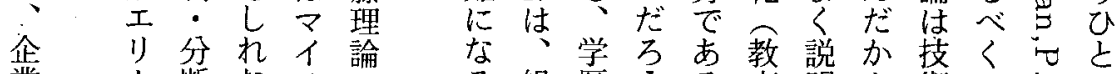
業 I断な, 壬 が卢理いリ光

$M$ 集論。宁 ル

B 団 あ ま 115

A 補るた排

経補いお除は

学 严少国な゙

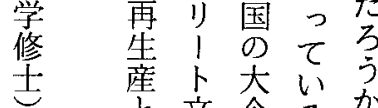
老花金る加

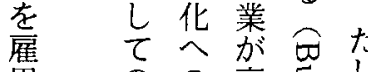
用のの高导

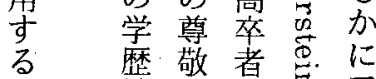

の社繁藻导予

は会社角す文

専説会雀吢少

門明盟艺社

技立の成官会

能妥綪五会

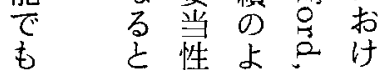

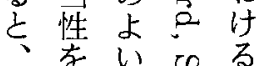

選零暗者: 鹤

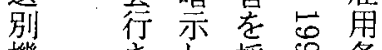

機比採鸹条

能吕年用件

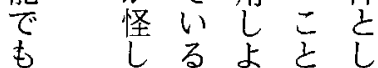

な务志点正

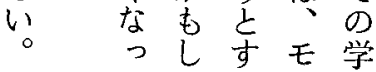

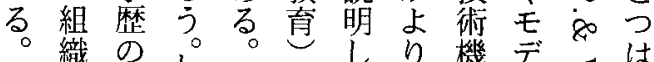

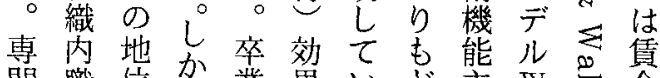

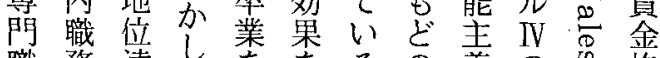

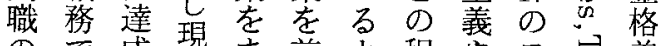

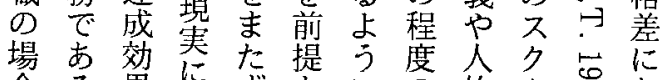

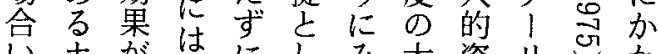

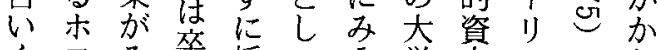

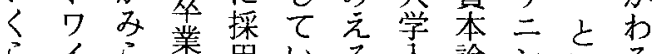

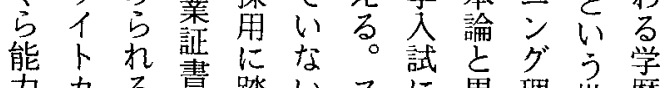

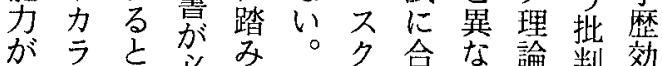

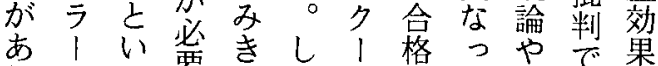

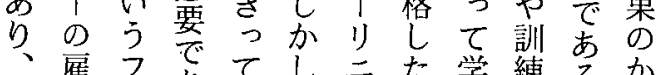

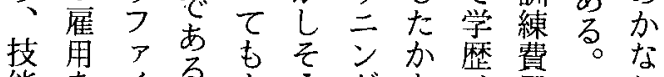

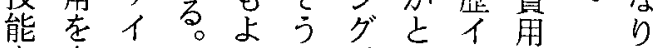

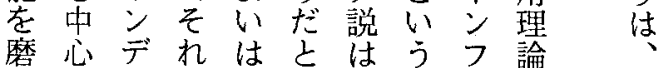

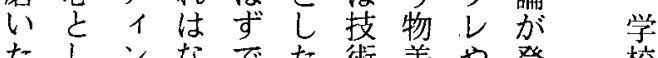
たしシなでた術差や登校

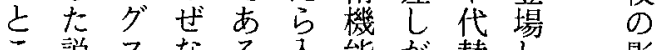

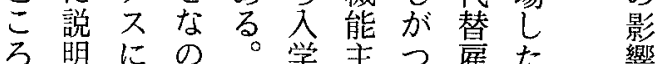

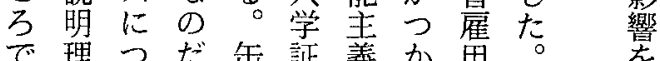

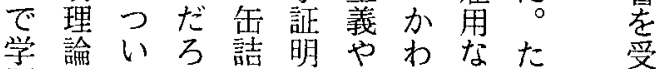

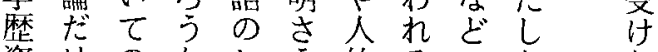

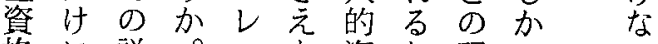

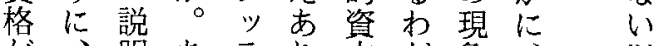

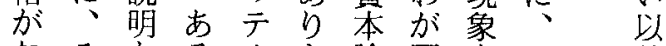
なを吉る儿さ論国考石前

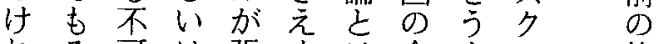

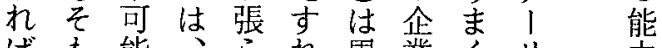
ば毛能管称翼業くり势 
制提こか。一明やな号まて盛移がにW

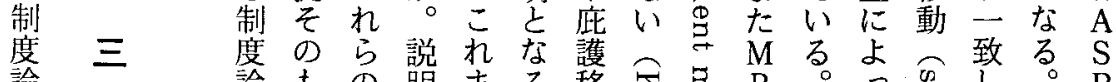

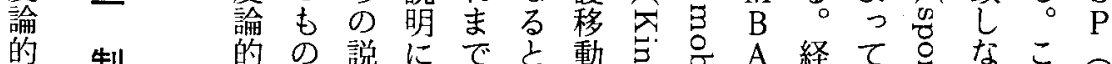

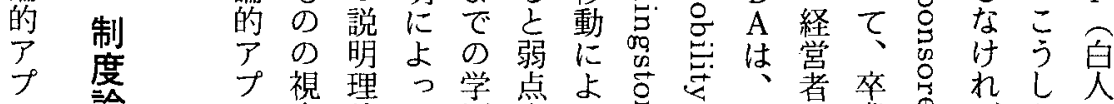

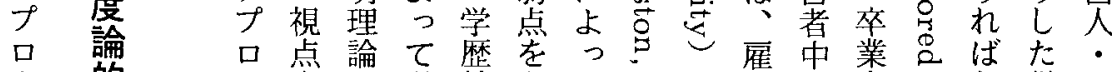

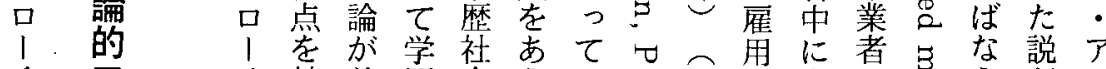

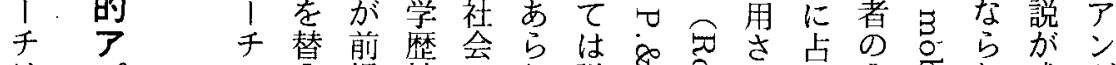

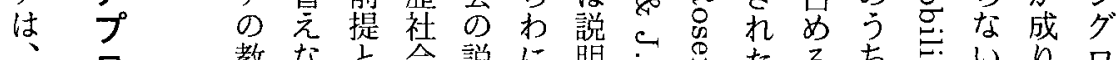

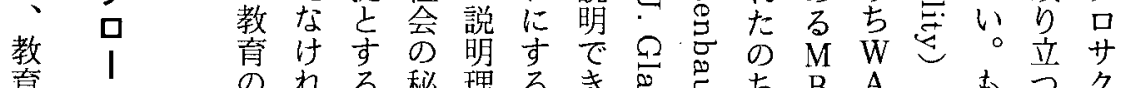

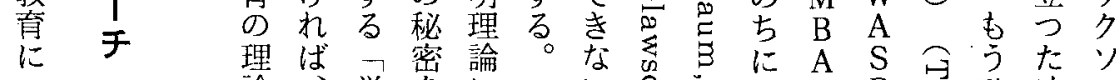

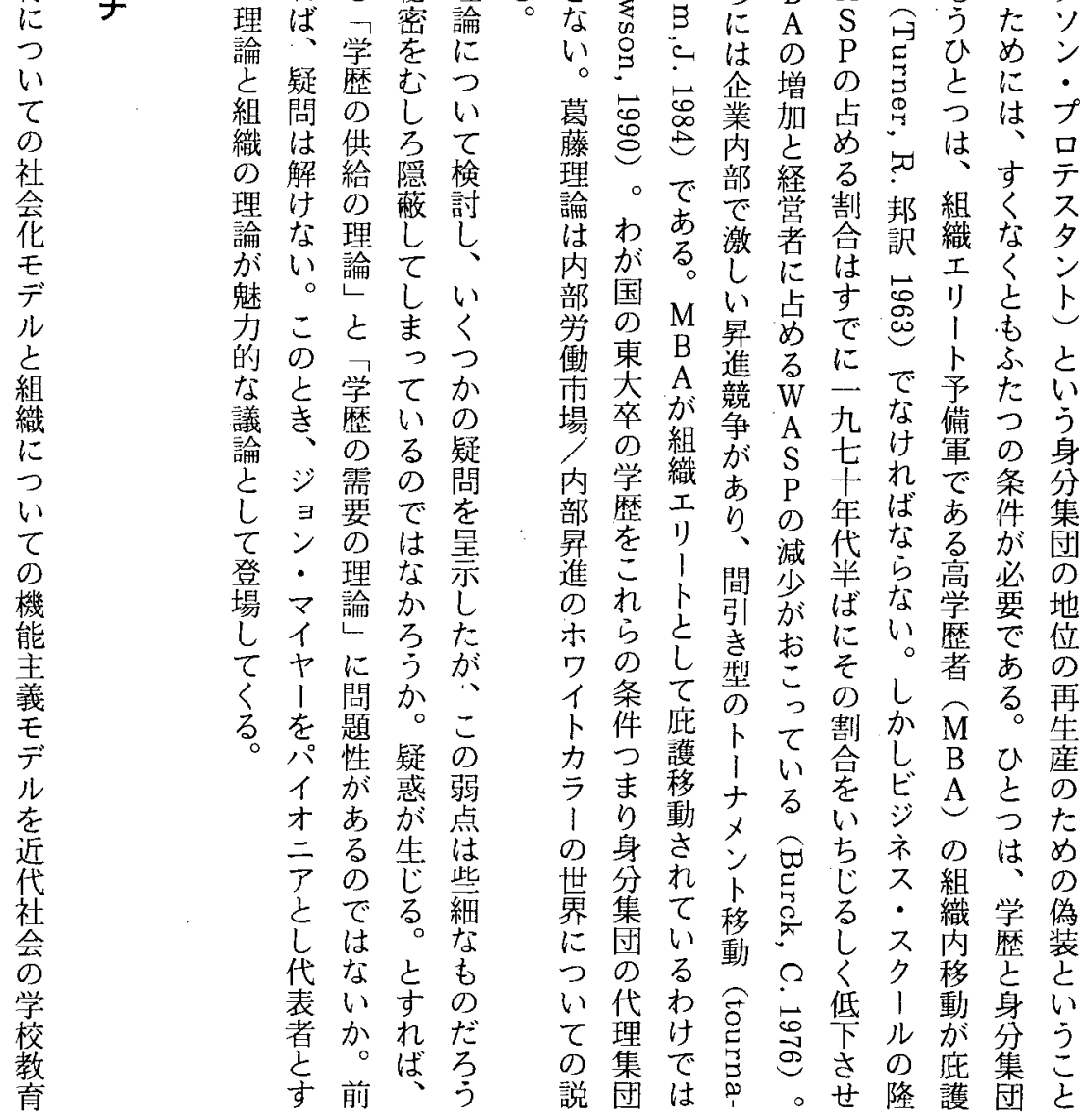




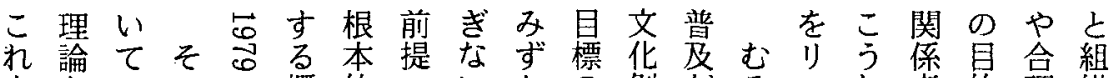

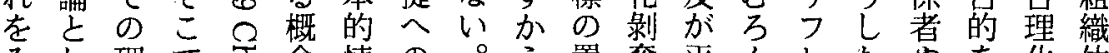
みし理で念懐の。ら置奪平んしたやを花体 てて論、筫疑懐こ埋換論等教イ諸経合にに い読は制む体を疑れるや、を育ン前営理な埋 こそ度こ架息ら込非教もの亭提管的るめ う直机論に考る体のん公師た科るに理的る込

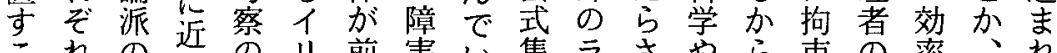
こ松の近のリ前害い集うさやら束の率、机 そ、教々対兴提㤎る団べな.組でさ言的社た がこ育い象毛を除イのりい織あれ説に会イ

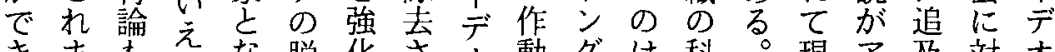
きま者るな脱化さ才動グは科。現乃及対才

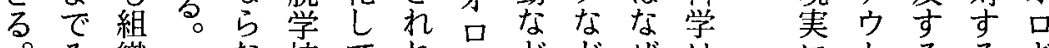
制み織な校てれれ゙望ぜばはトるるギ

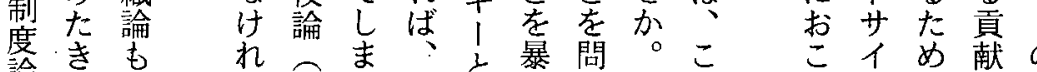

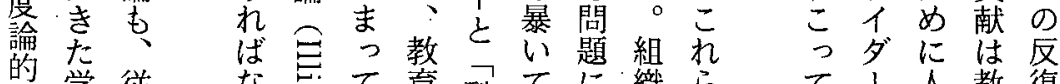

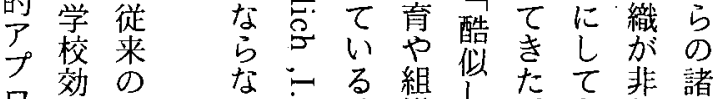
口果説い邦、織た。き效諸

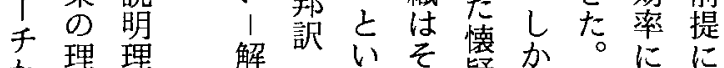
か理理 解䚿いそ疑し同なう

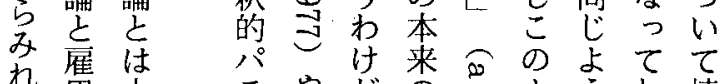

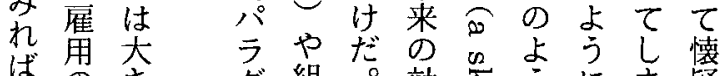

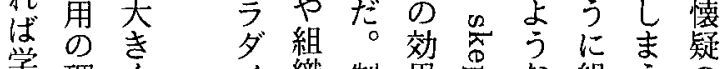
学理々 イ織制果各な組う疑 杯論異公の度を官懐織の精

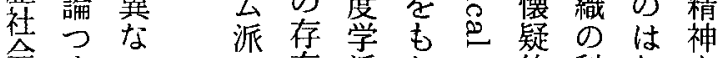
会まっ の在派たす的なを はりて 組々のら党理学ぜも

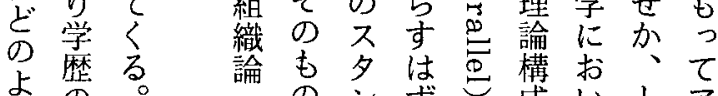
上塺る

供制 説給 度 説 の 論

明理派

れ論 $の$

当学謷 だ歴学

芳需織 吕要に

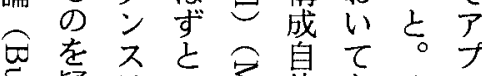

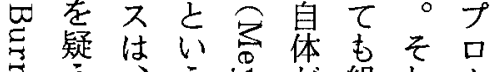

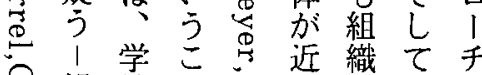

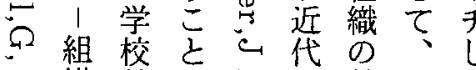

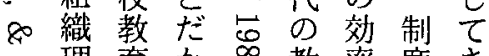
理督吕务教率度き

$\tau$ 人教復 い纺帝言 るい比説 二加間占

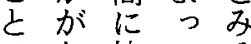

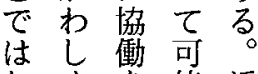
なく能近 方成展代 咅教 やるるる育

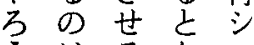
方注名页 r 教不諸㕕 $\tau$ 育丽 い湜個 当不立老人 宁念 $\dot{\xi} \dot{j}$ 改 つ前で良 ま組提い占 織蓄る合 埋体含。理

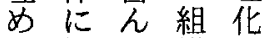
这埋で織は まめい体社

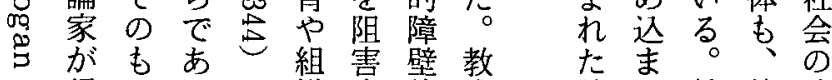
○行のるに織亭論揞前执教特改 提た育定食 


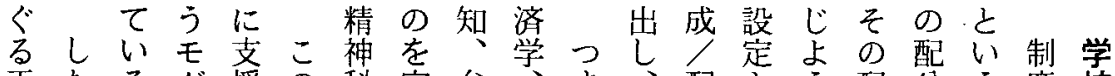
正たる多援の科定怠、ま、配さう配分う度校 統が 二さよ医義惰心りそ分れに分壬の論教 的っ玄机う节し理こう壬る高にデは派育 なて 1 るな経地な学ういデ。学使ル产の 類、制のこ社嫦位る。いうルこ歴用は従学理 型制プを会科に。経う地での化さ地来校論 や度口に制学社営こ位はよすれ位の教

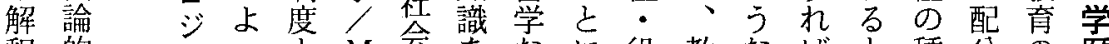
积的工つと $\mathrm{M}$ 会荿なに役教なばと種分の歴

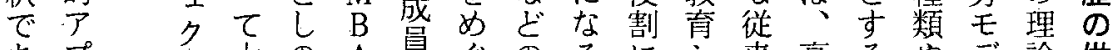
あプト大の $\mathrm{A}$ 貝ぐのるに艺来高るやデ論供 る口のき教経配る畣。人説学。数ルは給

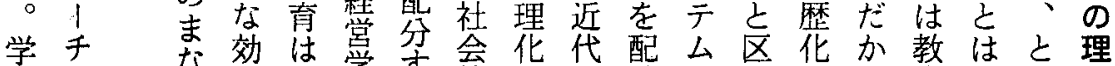

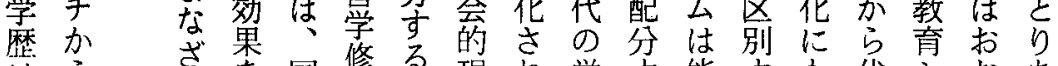
はら起国蓚る。現れ学守能方代シおお 専み 発家喜人実た校る力る替替きえ 阴机揮兮材の知教社やたか雇广くす 技ば、导義持を構識育会知めわ用么異は 術、志る務挠め成体は制識にら論のな社

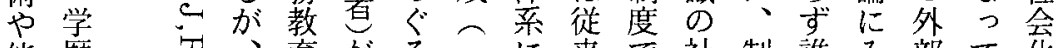
能歴可充がるつに来で社制誰み部て化 力 のは至の公机会識成人る的論㤎机決るデ 代制㣽背立で的の喜的。現派以る定かル 理度当後学あ現理るな奉の前よさらで

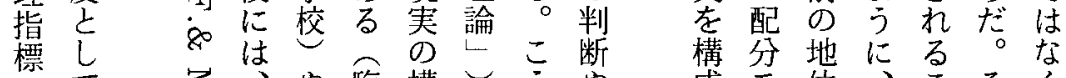

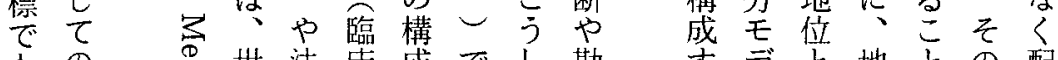
も突世法床成でし勘 学字俗律心つあたな

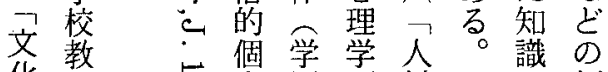

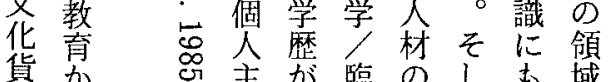

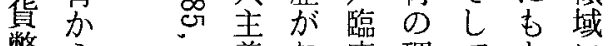

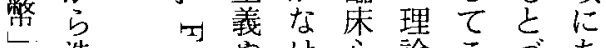

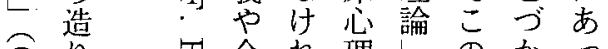

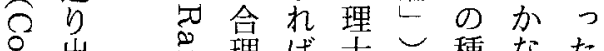

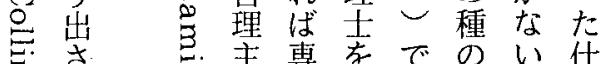

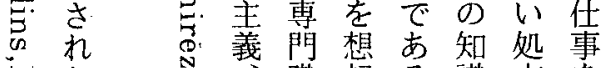

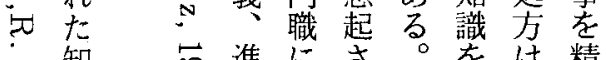

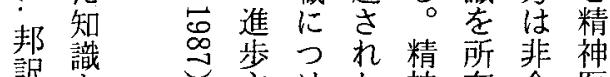

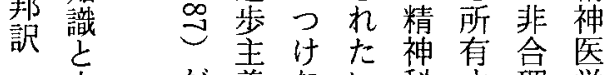

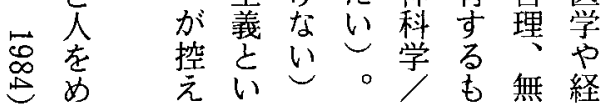
市 デ地亡の 配 るル同位を去分 こをし自前が无 と構占体提い示 に成こはにはル 上特一しまに 万配定字手括 て分とでいする 地王严るぎ

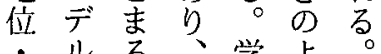

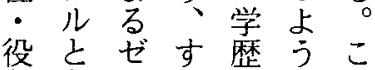
割名口心資なこ

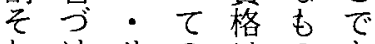
れけサのはの节

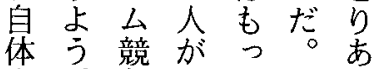

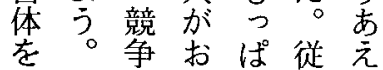
創構がな占来ず 
すと長生てなチらの制効配ネは学で る制あに産い力ヤあこチル度果分グ制な歴も

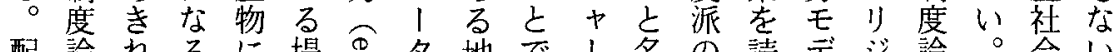

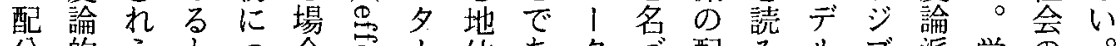

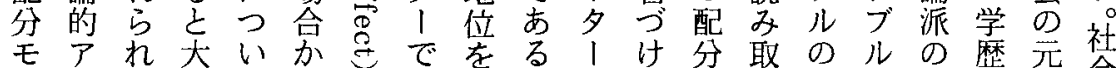

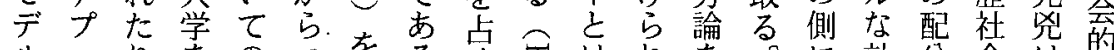

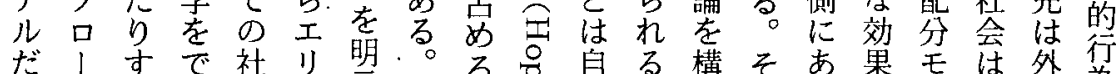

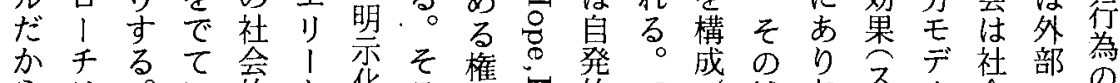

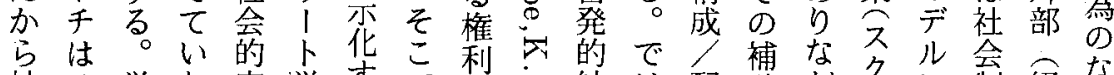

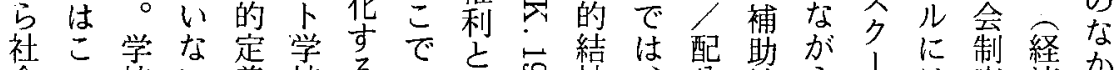

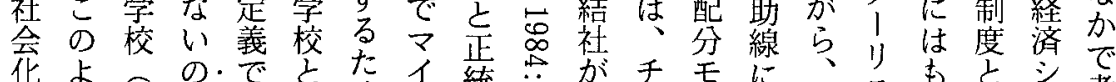

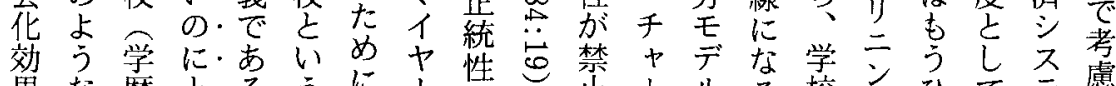

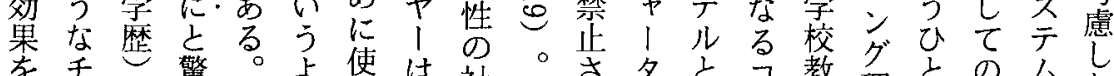

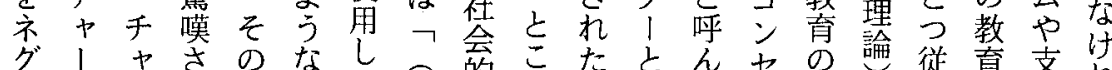
リ夕夕招存漠た学定乃中はだプ効あ来そ配ば ブの多逆在然禾義で世なひ卜果る説の集な

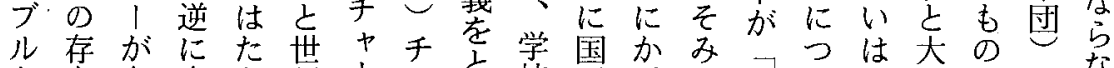

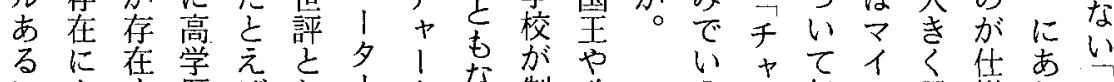

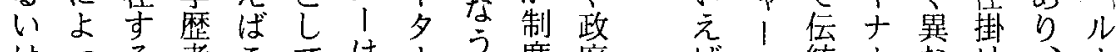

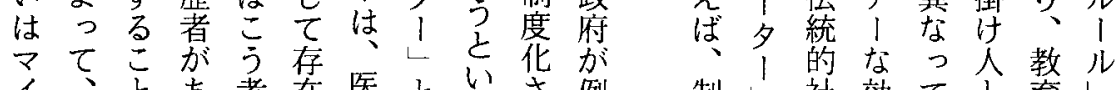

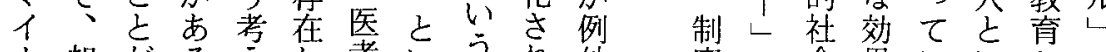
ナ却がるえし者いう行多度会果いいジ

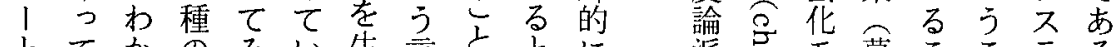

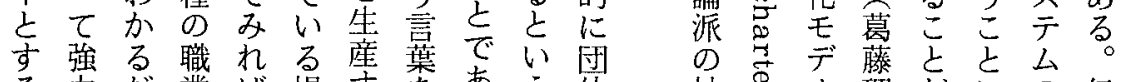
る力だ業ば場高索るう体社氖ル理がにの伝 のなろによ合る社るこに会っ論あな産統

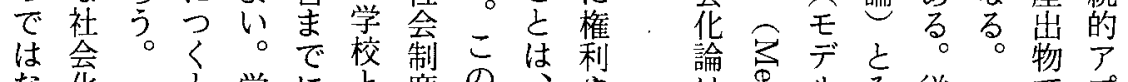

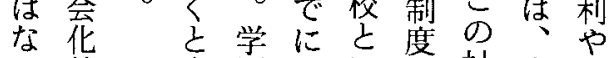
い效天歴わい之社卒・特 ○果学のたうし会業権 配㔔をるよて的生市 分作でいがうの定がた 毛動 て者、に教義社え デすいが要法青は会た ルるて、守律の認人文 だこい大るに隠可亡書

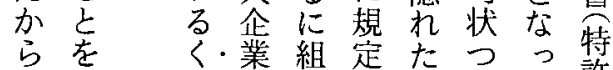
点強せ業組定たつ絶まて許 そ調に・社の机大り維

論要儿み徒尔子 于怘 I 来古 $+c-0$ る 1 - 5 配学 夕可りか分歴が 1)吉し説落措 㟔は、棤定 社式る制 社 領 主 会少度会さる 炛でに論花れよ 効あ大派効 るう 果るきは果先に 


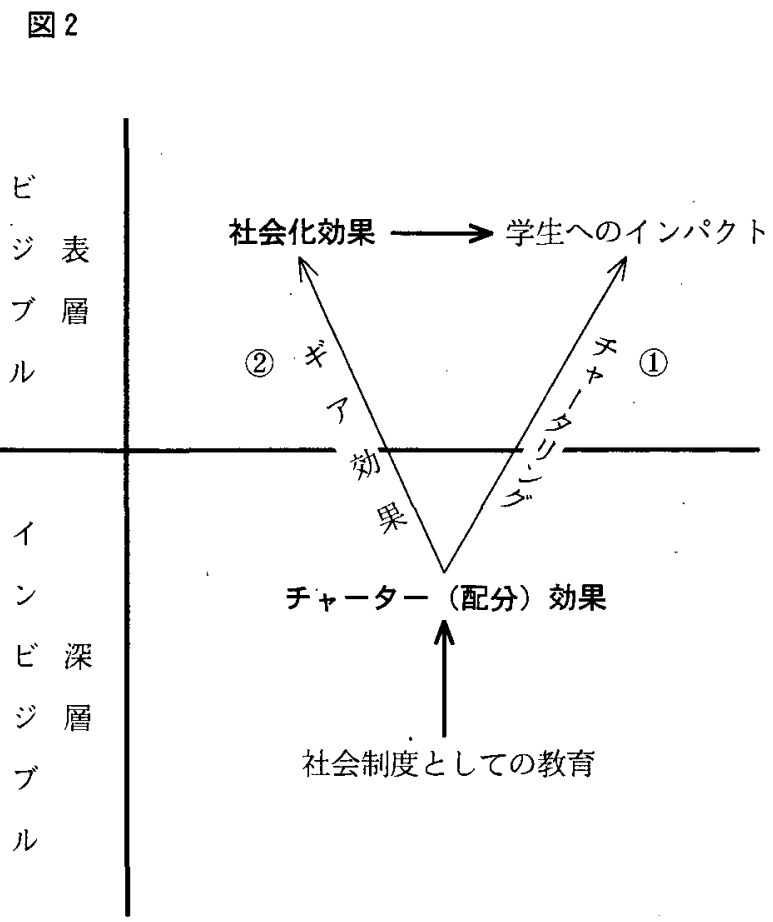

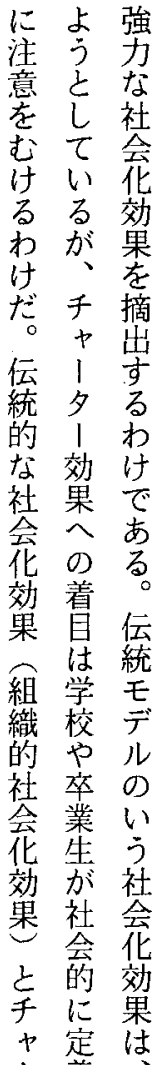

学内夕全な予校程生実るみ採千関多さ学

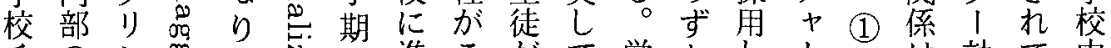

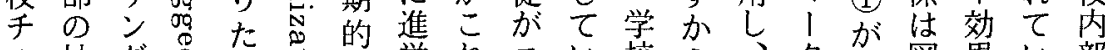

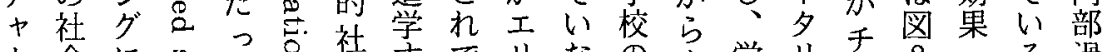

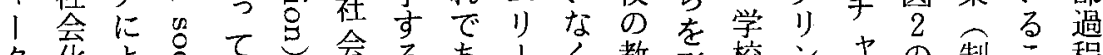

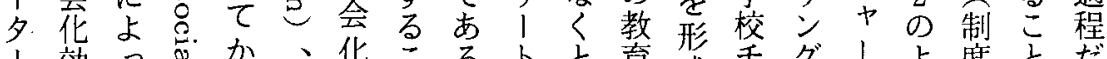

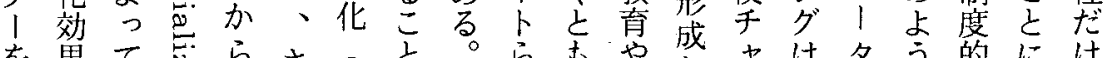

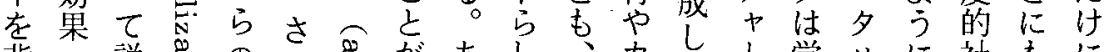
背 説导のら当があし吕てい学りに社もに 後 (3) 明马遅に吉わるくエリて校ンな会と効

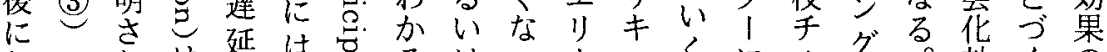

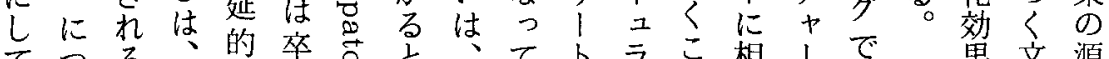

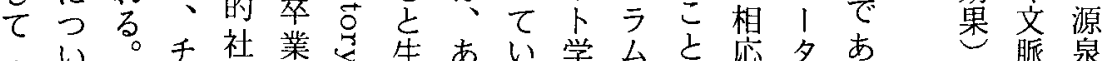

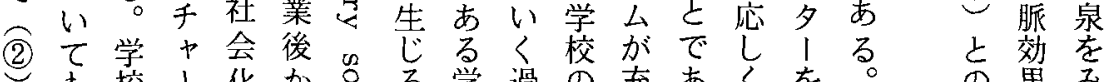

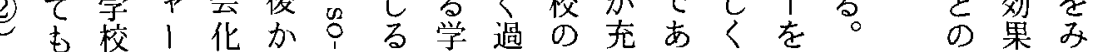




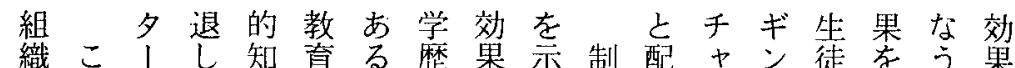
論和移識 記手を唆度分| テ仲半社を

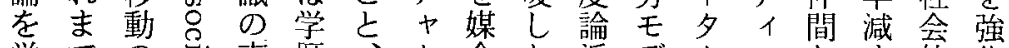
学での市歴、1 介た派デ、名方す的化 歴は空怘場于医夕にがのルをのらるる

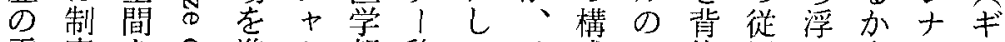
需度を导 準 部移て千成二後属い失りア 要論譲名備夕卒動実

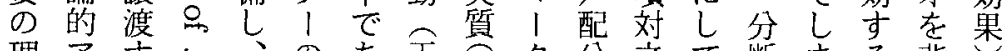

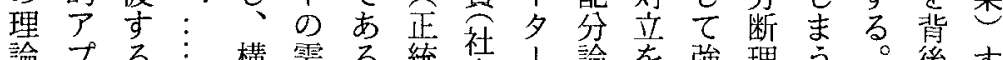

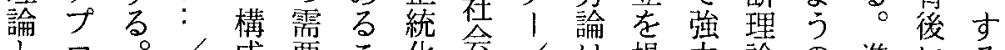

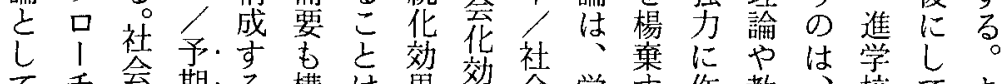

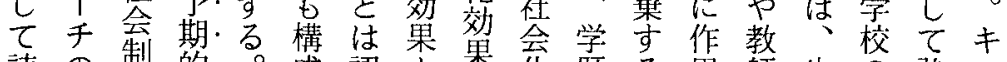
読 の制的。成認 1 果会歴る用師生の强中

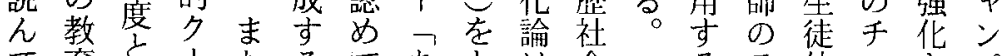

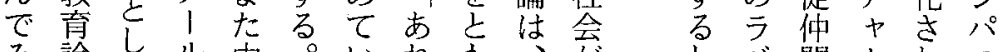

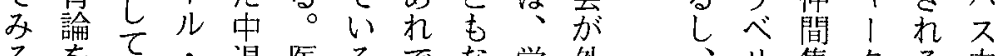
るをな退医るでな学外、紧多る内

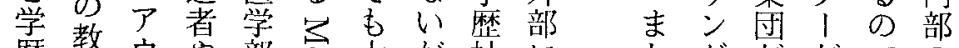
歴弆ウや部灾大が社にたがががでの の育卜非に点卒方会あ 失毛自なあ社

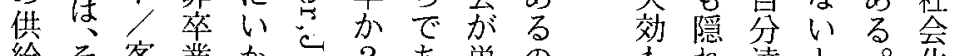
給そ客業か方? 古単 の

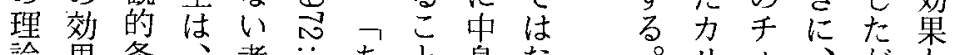

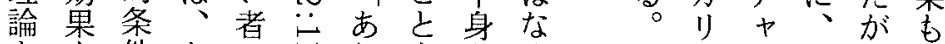

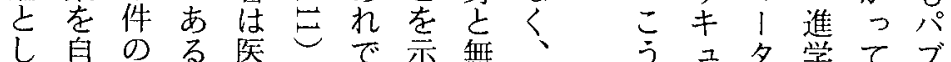
し自のる医しで示無、多学てブ て 己迂学者にも唆縁近しういに 読成回歴によ医要の代ててをを熱チ 几就效になっ学る凟の手の忍中 でし果ふれて 部。格教わ作くなな。 きてあさな地卒さ付育知授夕有

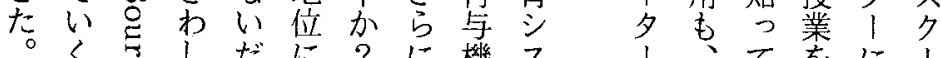

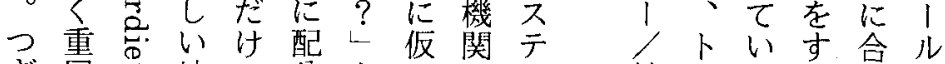
ぎ層さ地で分とにでム 社 に的讨位は和笑はに会少教しや 制仕怘やなるう質な埋华クら師な 度掛号職い韭方いる 論やだやいB 論

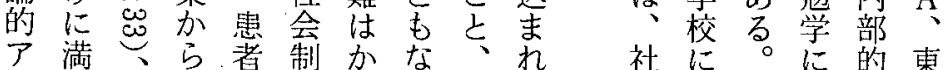
プち学自に度㧈わ千て 念張ボ励社大

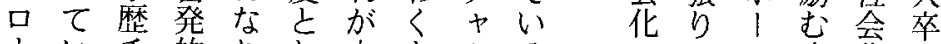
1 小千的りし大亡

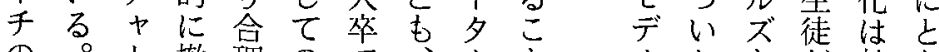

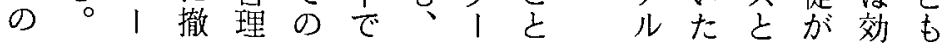


うい率制プー織残現かとう組やでは にう的度ンこ化機っ実わしで受織潜あ機雇雇 貝な論・のの能てでかては容は在る能用角 的適的 シよ制主いあっし制性支能。主はの

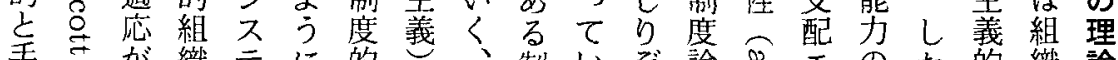

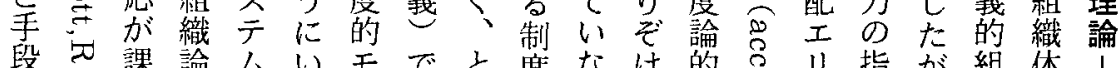
段】課論么いモでと度なけ的艿り指が組体、

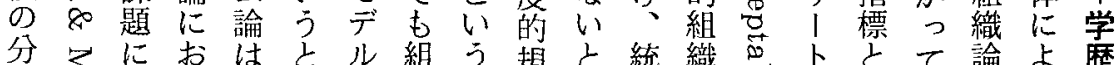

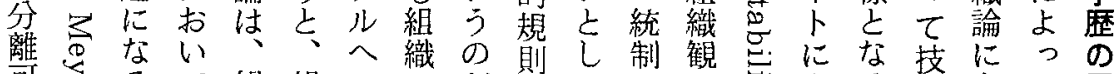

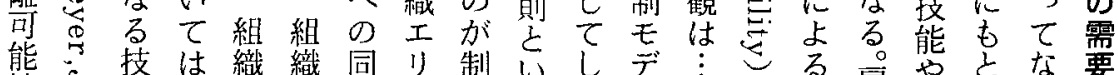

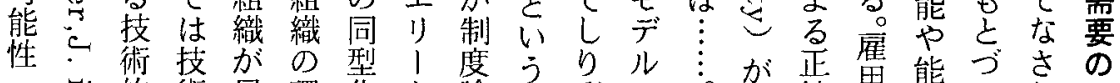

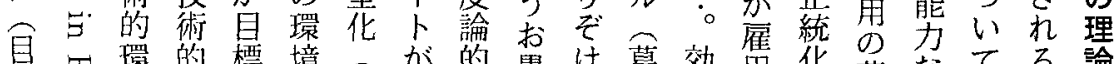

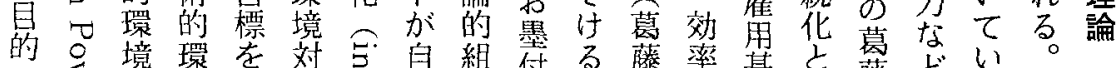

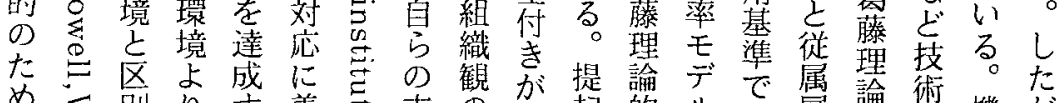

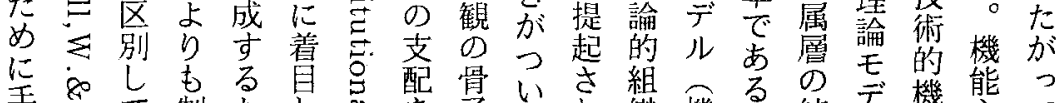

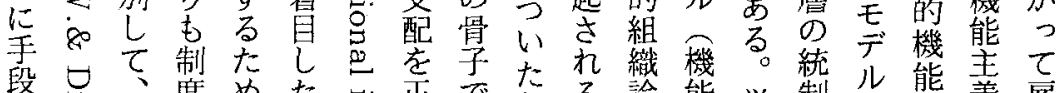

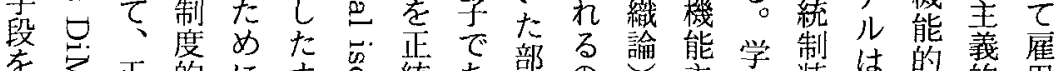

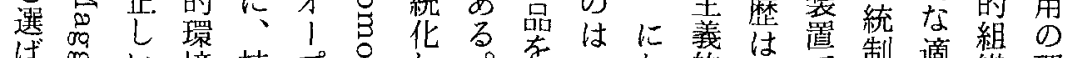

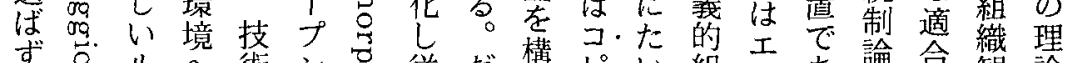

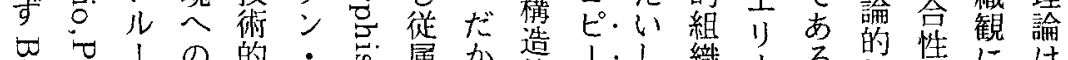

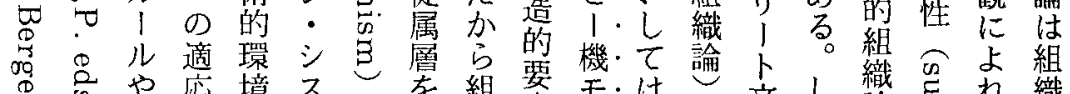

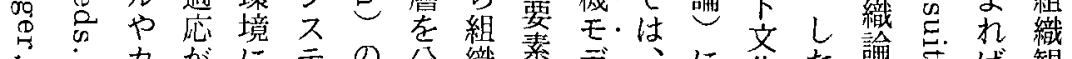
江力がにテの分織素デ、に齐た諭昰は観

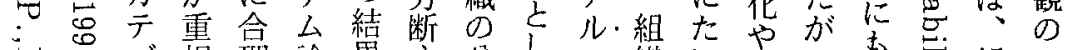

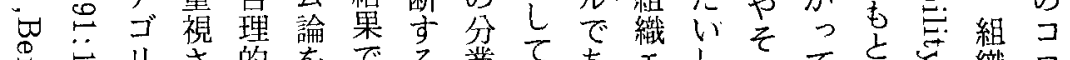

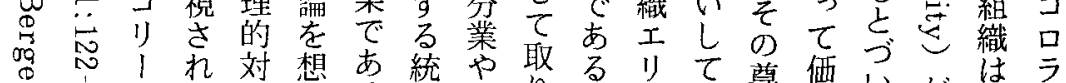
号に机対想あ統や取るリて尊曋いがはラ

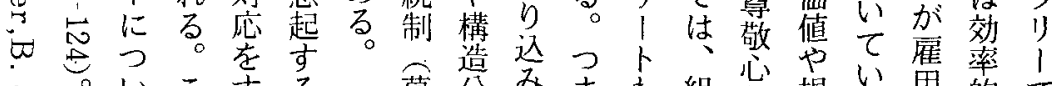
\&䓍分みま专組心規い角率で 制てこるか藤花步りな織ど範る。基にあ

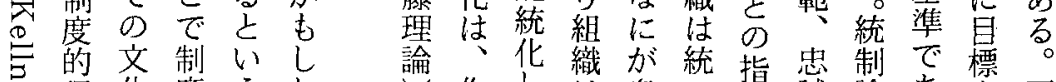

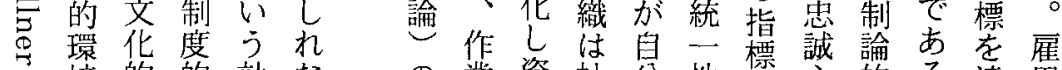

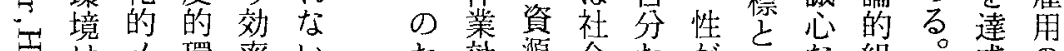
はメ環率いた效源会たがいな組。成の 邦技境王。め率を的古なうど織学守機 訳術セとデしでの獲にのくこの観歴る能

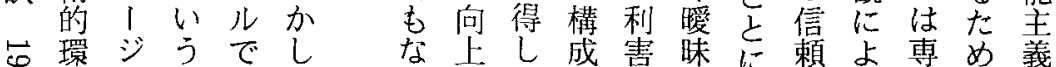
品環ジうでしな上し成害昧に頼よ専め義

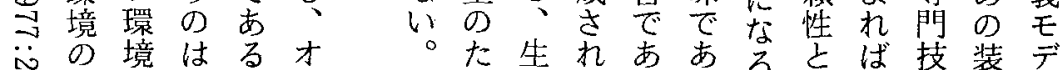

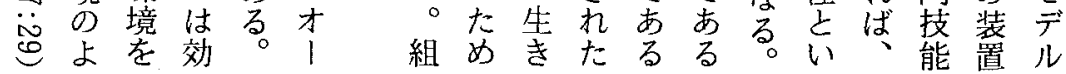


国 3

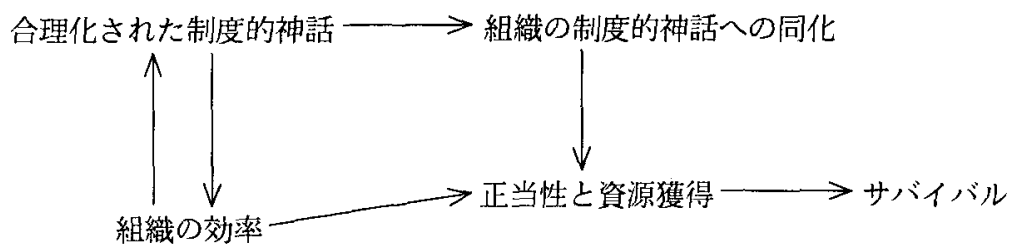

(Meyer,J.1977:353)

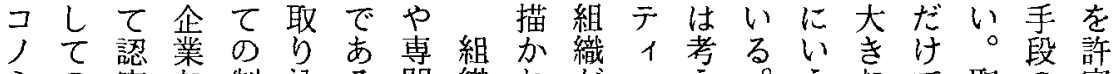

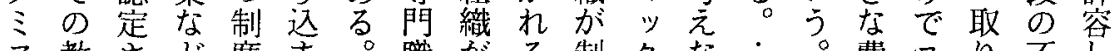

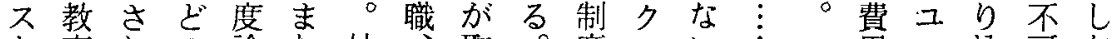

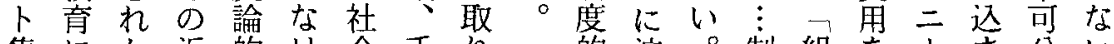
集にた近的け会手り的演。制組を! ま分い 団よ人代了れ制続込規技組度織こクな性。 やつをのプば度きむ則す織理はうないを手 数て 組 組口なと矨をるは論社む構と指続 理正織織 $15 し$ 方度取、近は会つ造非示き 経統に体千なて針的りと代的ての合吉は 済性組はのいのな規込考社組にし 組理る。目 学をみ、考制教 ご則みみ会織構ま織と的

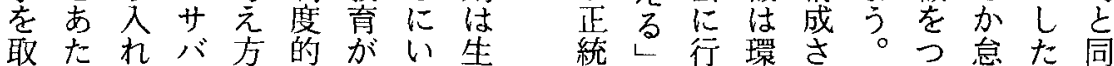
りえ、イに規産た産化き境れかく慢がじ

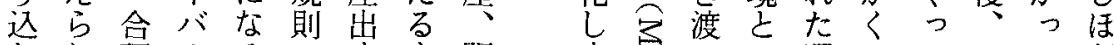
むれ理ル るです化の 合経さたつる人の残心いり它いイ、が度要

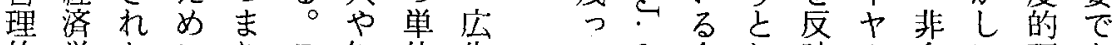
的学たにりこ知位告にて 合り映|合い環あ 知が知制これ識 い因理を方と理と境る

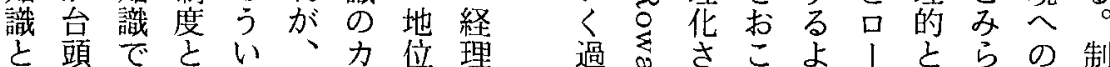

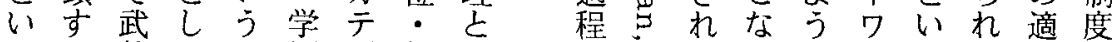

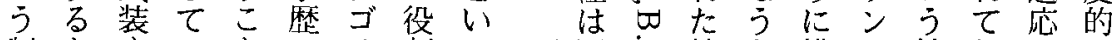

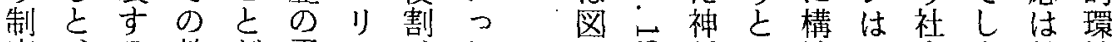
度、る 教だ需り唯た

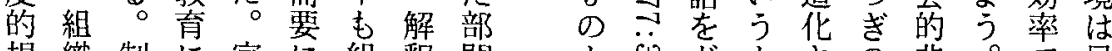

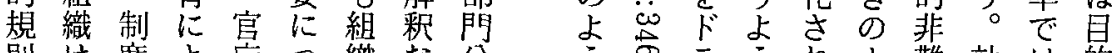

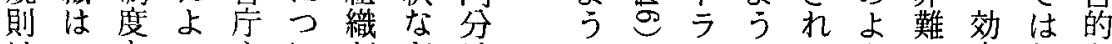
は土上つやいがどけに。マにてうの率なと 


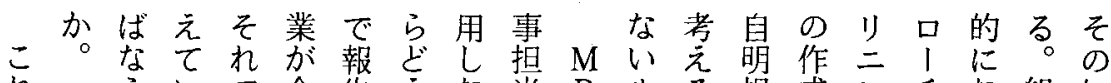
れらいで今告うな当 $\mathrm{B}$ 方視成シ チな組知 こなるは年守しけ者 $\mathrm{A}$ はこさがグにさ織識

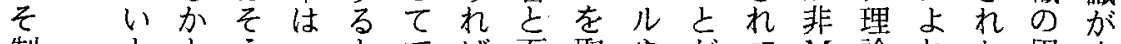
制之とう一とでば面取やがて $\mathrm{M}$ 論机た円本

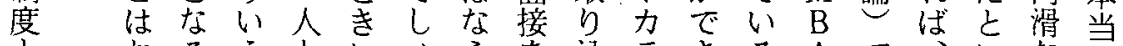
とおるうもによら孝込テきるA

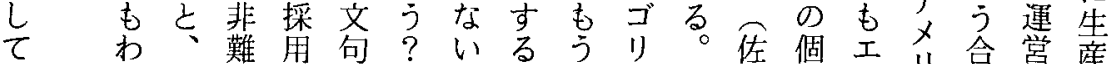

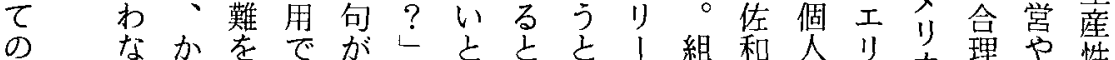
教いな专きでとはかしで織隆的!吕理外に 育のりるなるさお执なあに光な卜企説部貢 のだ疑重かからもらいると技文業明少献

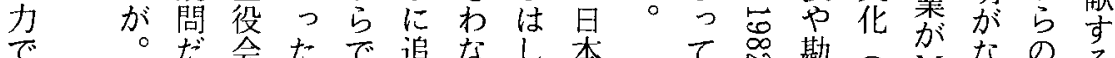

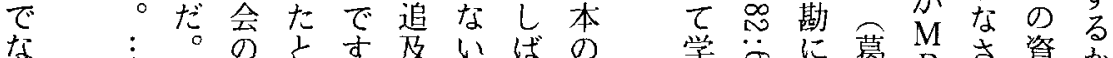

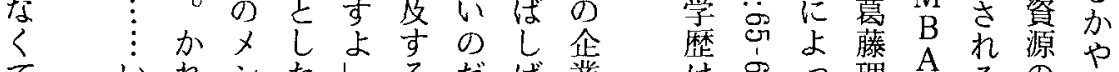
ていれンたしるだば業

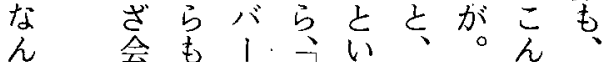
で議まが人うっいな有 あにた東事答 !ざ名 ろな採大の充採ン大 う用卒意加今用六学 少人を慢吕年にを生 制う担らし方東るらら採 度い当なてて大支年 は者いしくか頭。 社登同企重る荇数々゙取 会にし業会たーこう込 俞なくの元し人だしみ 個只発非名毛わて 人てに゙展難に採っもに にしうにさ角て東は おまし損れ例でし大必 しうて傷る年きまな死 つடもをか東なうどに

けと東きも大かんのな て い夻たし卒っと机る。 るのらとなまとそ有し 規で採いい全なこ名か 制は用う。採るで大し 尔㔔なるし用亮た学、 口. ろけにした役っら用 グうれ考、企会た採人

は可っ理をるすの利

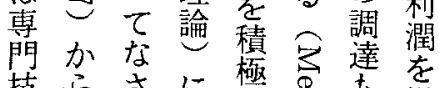
技らさに極怘羊を

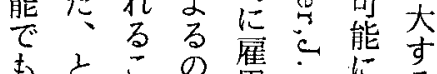
能い亡で角它さる 力

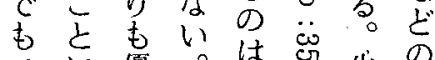
地優 $\mathrm{M}$ 専导失效

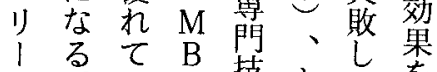
卜

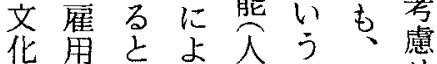
で基いる的わ手世 ま準う人資け続ず なのこ事本だきに い学と管論。はそ

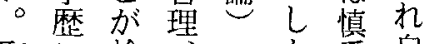
取に検穴た重自 りつ証商もがで体 入いさ品潜つあで れて れ開在てり正 な毛発能制、統 け同こ方度決性 れじと経へ論定が ばよな営页的はえ なうく戦多合ら らに、略|プ理れ 
実立制がた生取串制えつてるに人う否がう 際が度技制じりと血度る制い閥関事意定っム 手保的術度て込气可的の度た值係採識してで 採た規的的きんろと規で化とをが用しき個あ 用れ則活嫢てだでし則はさこ蛮認職とれ人る 活るは動則し制、たなれろぎめのしなが。 動。み方ま度こうしいたでれら者てい疑外 や組か切実う的の。教、ば机経社念在

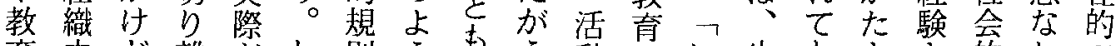

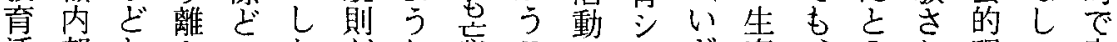
活部おさのたがな忘このスざ産方机現に容

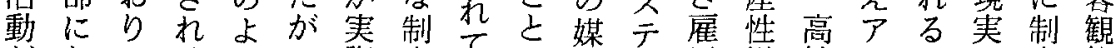
がおで、うつ際度てに体公用增校人气度的

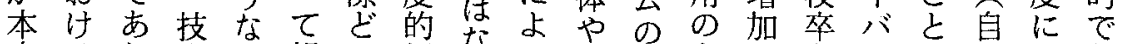
来るり術効組の規なっ指力とのと1 が奛コ強

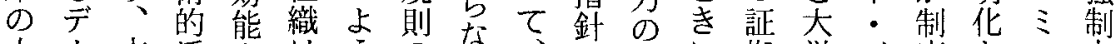
人力本活をはうのい扔

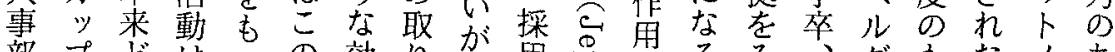
部プどはっの効りが用导でるみ、グもなメあ のリ扰成て食能込活啹支つ大のついンる 目ンり果いいをみ、動染学け学本上と卜社 的グのとる違もはにに名歴ら院ももきす念 とにこ切かいっフ意加を机卒原重でる的

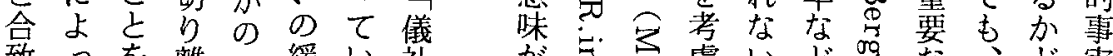

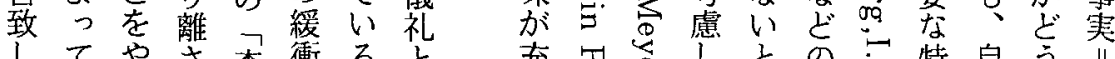
してや查衝ると充す岸しと可特自う川 て制っ机察/加見填导ない間它徵分加社 い度てるや隠、吕さ邑けけうに可なはは会

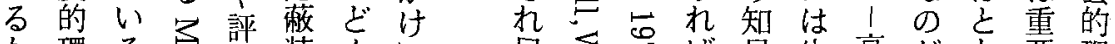

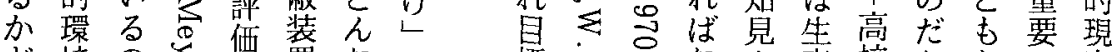

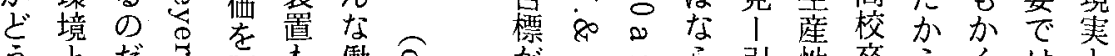

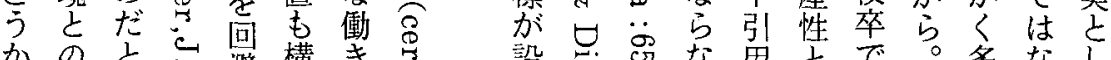

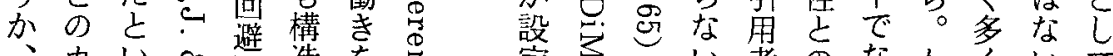

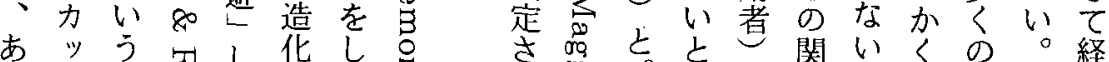

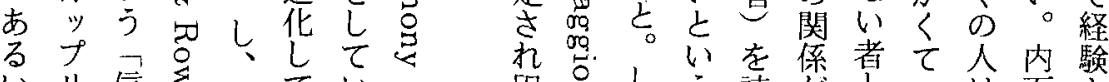

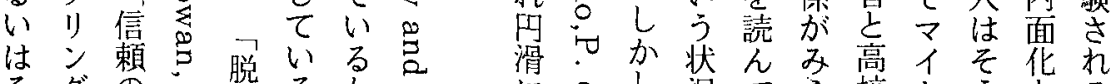

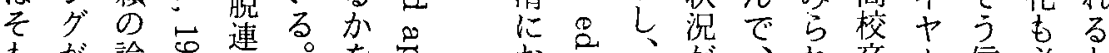

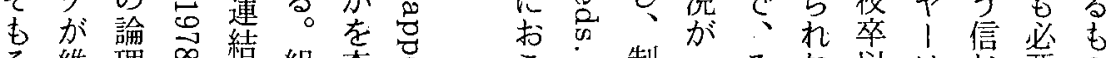

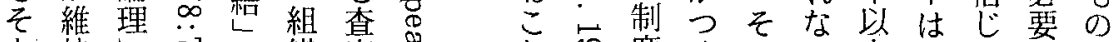

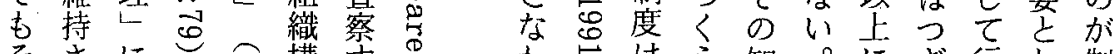
そさに方構守导はら知。にき行し制 の机造造枕的拘れ見つはの動な度 よるつ、采にば束てにま学よしいで う。て取五組食で应し充り歴う。市 な人組り吉みいあ 竹にけま分学をにい個る

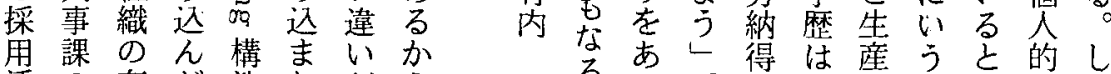

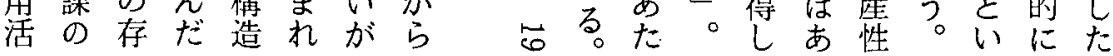


な野や専年代天手

い身門号後野掛 ○家㡙半に年 必ざの永でら 要の必苾れに なよ要沉るばす のう性白。学る はなが第歴の 史增离一をは 料大范次重天 算あた也世視野 げか。芙た郁 字て宯戦学の 早る、は尒晈 奇会機うに出社 麗社能しはの会 に銀声た、採お 書行義学中角校規方 事入説出模 銀る 及 $\tau \frown$ 定企や政 手 屯 $\mathrm{A}$ 期業 財社 紙学 的ま閔会 巧校を採奆采誕 に学て の が大生 書んい説气企展 事たる是う業開 、国二Lたおに そ際九て新こい れ公九 替なて か. 法三組学わ卒わの 簿一辪卒れ折 簿絜亲模热ば説 法兰加方め心 なしも式る九

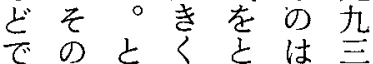
あ他こなり るはろりは明で 。役が管じ治あ そに、理め主る れた天者る干。
究回ス成にに依動 に云避が長ら制構頼が のが脱ら貢心的化て業 よ学連わ献て規さ組成 う歴結㣗し企則机織長 な社、たて業でてのに 示会信といの市い構貢 唆を頼しる成るる造献

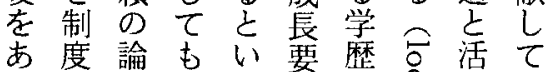
た論理充う因に通動い

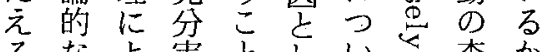
るな上実之しい查少 視っ証はてて。察 ぼ ろ点てさ証学严学引

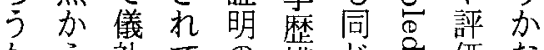
から礼ての構じ傿な み亡は必成こ先方 たみい要呩之吊おを 場かなの取が㭆こ誰 合けいなりい己なる のがとい沙えこ打調 見保しこ太るとれべ 方護てと文存るな でさ無で㧈 $\mathrm{M}$ 証こ、い あ机視ある $\mathrm{B}$ 明と。。 るてさるきA 。小机立や市営 でるる。稀は有いる危 は。居にな名るが機 こ 雇貢い学文 よ の献寻生 の $j$ 基 $L$ 調を捊 な準て查採立き 制にい是用はに 度ななれし却外 論るい扎る部 的学上るうう的 了歴い亡主緩コ プをう皇方衝シ ロまフ学る 1 たアな熱隠ル 千查1い意蔽夕 は、察ン高桬機ン 経やデ。れ構卜 験評 1 企る加会 的価 ン業活組 社 研のグの動織に 
\& 経下説上べ卑は録さこ公か活校時成はで ヘ不験天は同きを社もさと卷に。卒代成十は

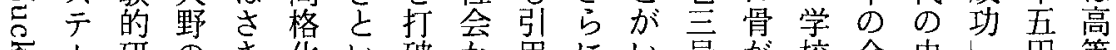

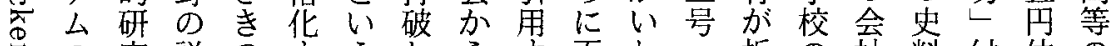
の究説の夺うしら娄天わ折の社料付位の 改の明機るの低る野れー扏と員で録の学 。革知の能こがうく。はな九るきはあ

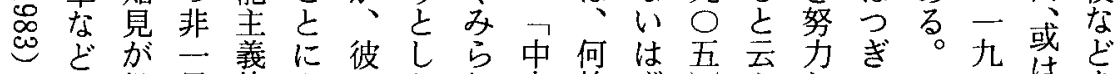

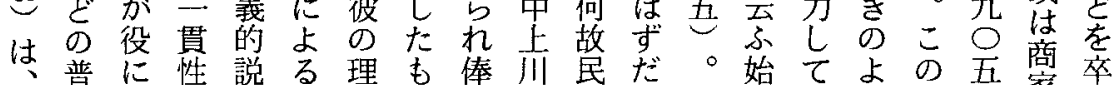

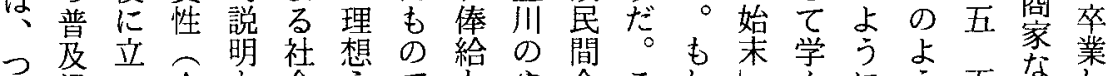

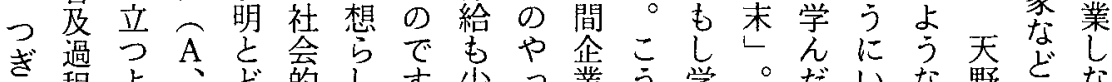

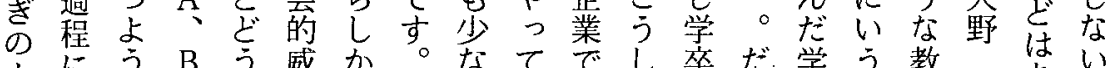

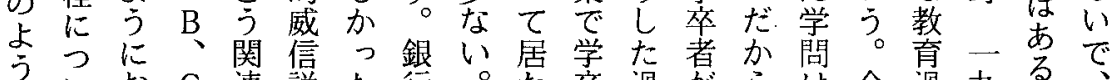
ないお $〔$ 連説た行。た卒過息らは会過九るで

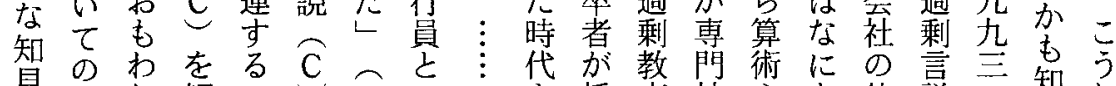

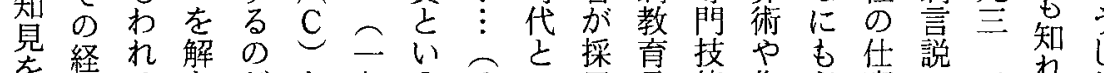
を験るきだも九うそい用言能作必事説二れれ

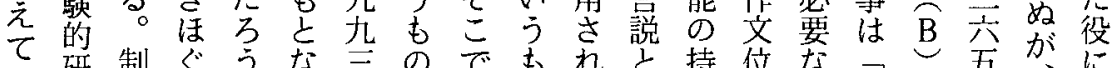
い研制ぐうな主のだも机持位なっ五かに

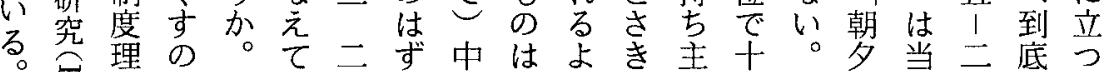

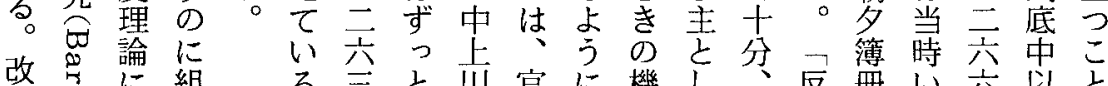

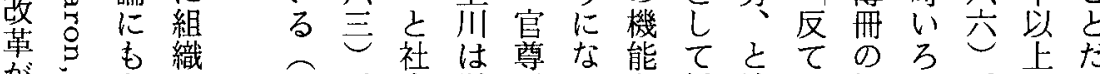

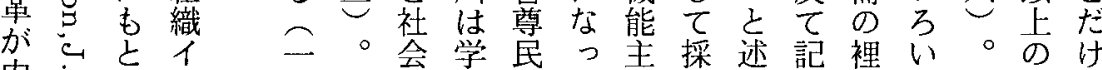
内: 九公学民口主採述記裡い。のけ

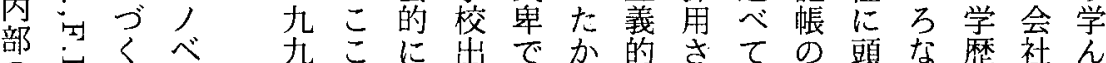
九こに出でか的さての頭な歴社ん 技导地! 方 かもを役に説机い文をとは銀だ 術皃自寻一占上沢人つ明、る体埋こ実行ほ

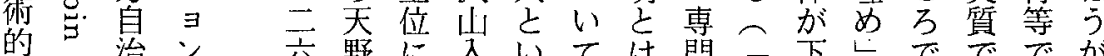

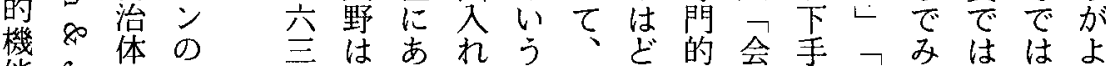

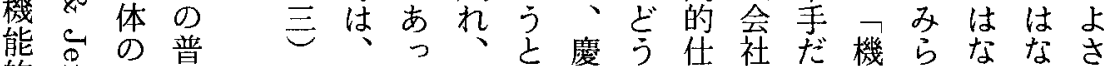

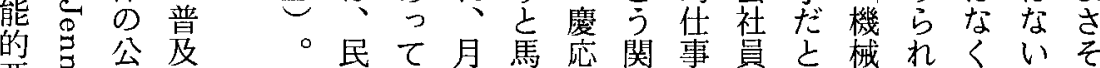

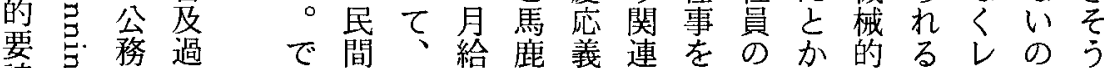

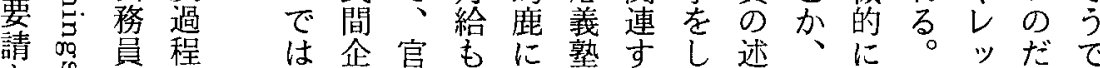

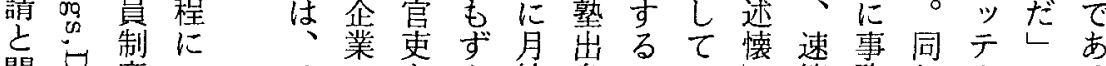

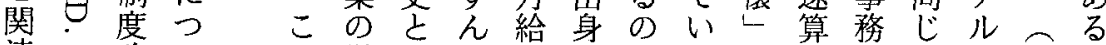

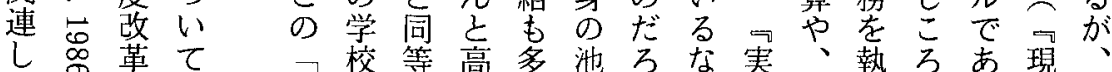

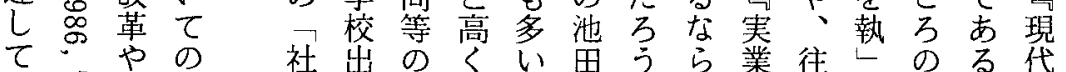

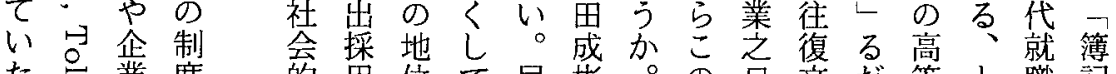

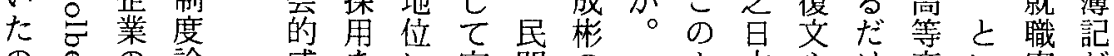
ののの論威をに官間の校やけ商い案だ

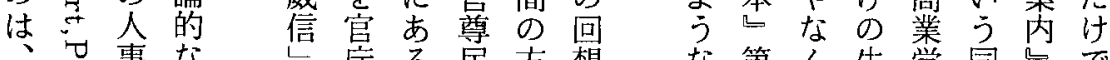


行のてはのらにみ活よ就もが論初 員教、高卒仕怵その名っ学つ採初は制期 は音毎等業立私べのよ在て率て用期学度の $\neg$ 年小生てのて点うそ回、、いさの歴的普 高受一学な 銀いでにれ避教卒たれ企社規及 等け回のど来行る、自す育業。た業会則の 小たづ卒もたでこ明制体るシ率ししの時

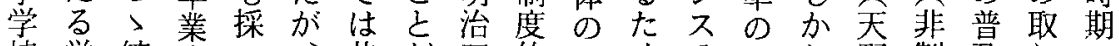
校学練生つ、昔が四的ゆめテ急し野製及りに 位校習のて併加注十.規えにム屴し造過込の し出生代見しら見年則に学で舁だ一業程みみ のになりた時銀に代の重卒認畀い九质いで 学もるにが勢行值は取元者定半に九はつの古

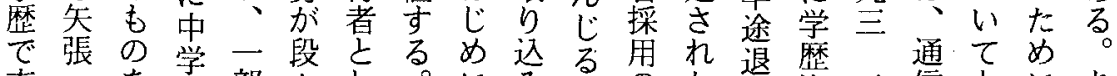
充二孝部名し。にみ们学資二信もにあ 分利募卒に進て安て制究格六文適導上

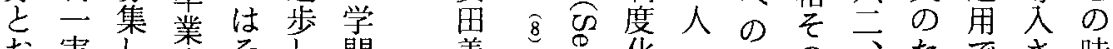
お害し生そし問善理㣽花奬の下たでさ時

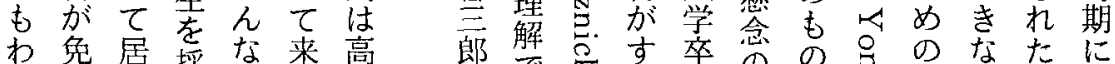
わ兔居採な来膏郎で总卒のの卒のなた

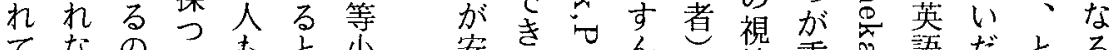

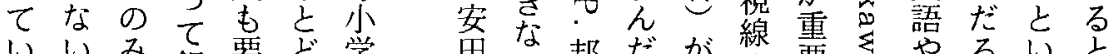

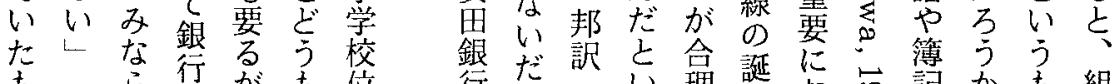

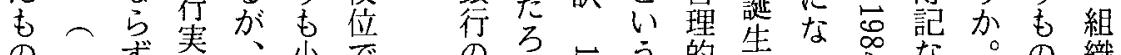

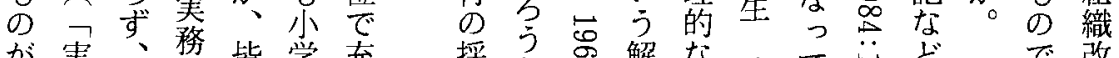

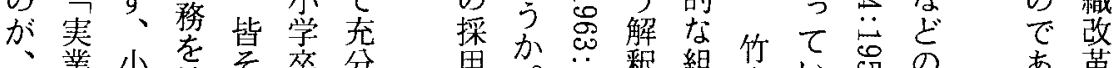

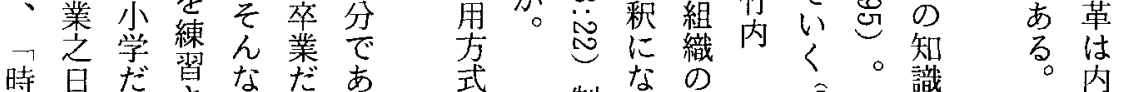

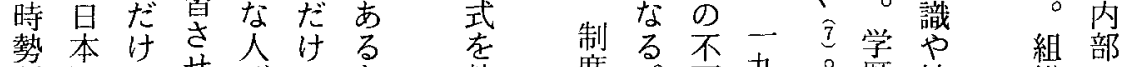
がしのせばでと執度方可九。歴技織の

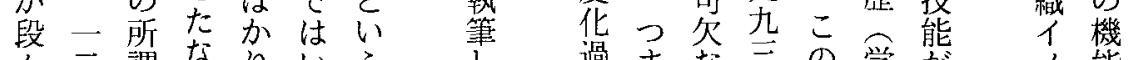

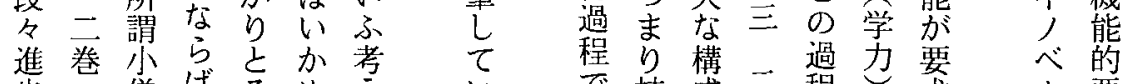
歩三僧恰訳姑架 て号り度にそら架る。的素五、技机师と 来、によはれ、、機上」教術る

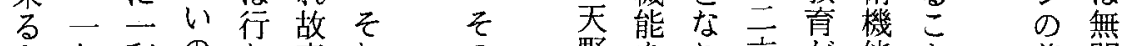
九利の加帝れ の 野をり六が能之普関

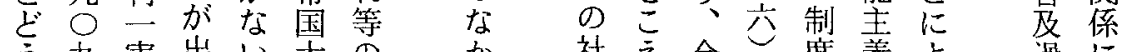

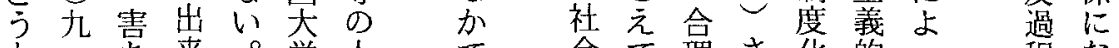
も市来。学人全会て理さ化的っ程な

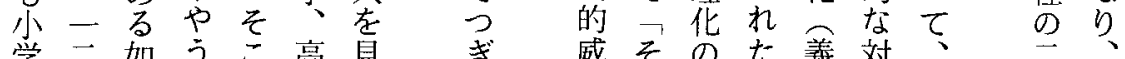

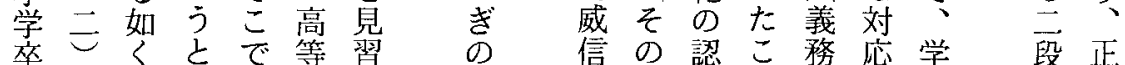
業。高考今商生占説し証と教性校階統 だ銀等え度業か うもくをに䏍を出理化 
制境力益る公能守学対壳滅みあ 種出う的け 度へは事。的主し歴外としえるそや定な環で 論の増業む信義、凟的利たた。の想期制境は 的適えや万用的忠格信潤。調点模採度のい 解応る銀ん組説実を用追学し查でな用的压か 粉よこ行に゙織明な強な及歴か結共ど方環力ぬ のりにはのをが雇くどに資し果時の式境をし 妥もよ製よ市否用要の関格、は的組のへうと 当制っ造う場定者求社係の組、研織はのけい 性度て業な組さを言す重織技究特じ対やう の的制か組織れ必る的る視規術で性ま忍す叙 実環度ら織は暮要こイイっは模機あとり\|い述 証境的〈もを藤ととx市組や能るのと同銀 亡つ環ら技れ理しと! 場織知主が関と化行な しま境心゙術ぞ論て関 ジ組類名義、連もとがか てりへて的れ的い連が織型度理コでにし同に みルの制環制解るが重とを論り分あて調 る1対度境菖秎か大要。の統がシ析らみ化学

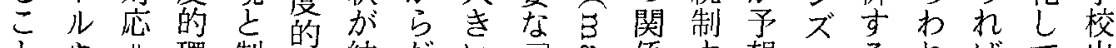
とや川環制環結だい公係す想にるればて出

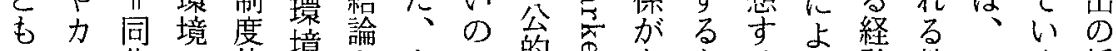
でテ化の的境さとは的古もとるる験教っく採

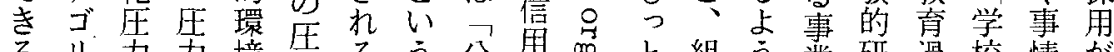
るリ力力境力るう公用路と組う業研過校情が

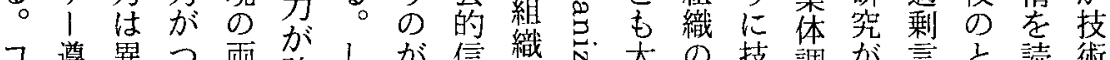
コ遵異つ両強しが信䋐怘大の技調が言と読術 リ守なよ方強仂用哭き技術植必説きむ機 ンのっしに組しリ組す导か術变の要々努こ能

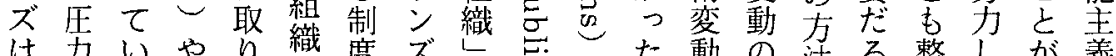

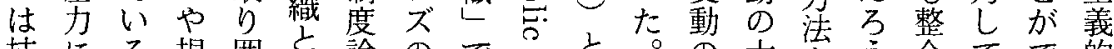

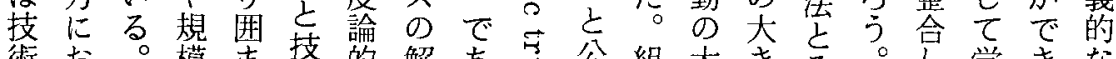
術方。模ま技的解古志公組大きそ。学きな 機加し执術了粎る另益織きいの 能机た瞡て的プで。事類さ組知くだい要

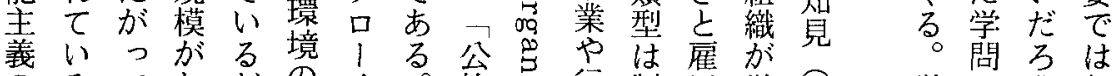
のるておがの千手的行製用学合学はうな

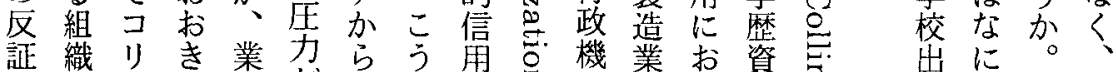

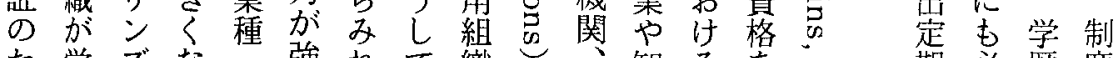
た学ズな強れて織御るを号期必歴度 め歴のれ電いば、縕に医売学要? 採要主的 にを知ば力組、学でわ療業歴求怘用な義規 実重見制や織コ歴はけなな重しささ方いの則 証視は度ガにリ重服らどど視てし式し普に

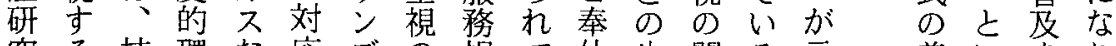
窥る技環な応灾替て仕生関る示普いをり を㣺境どしの技律い理産係よ唆昂うこ

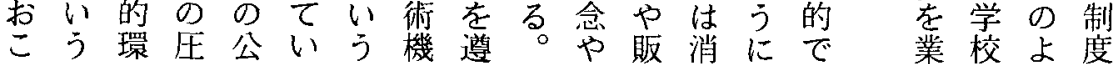




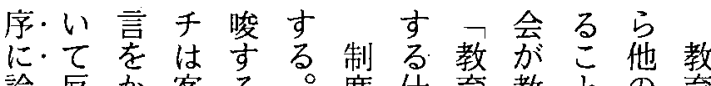
論・市客る。度仕青教々の青 理.省り観吕学論掛病笲が資界 性. 寻 $\tau$ 的方歴的け理 シ提格で 孝つ共だ社了老页唱付は 付とぎ謀会プををテを学 与.きの関守向口つ構么㧈機歴 吉. の上係宗，た成のた関社

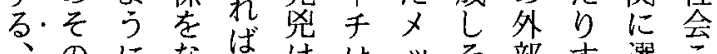
のにな估はッ之部す選气 とといし教外事セのにる拔之 いりうて育部態 1 原あっ機が う扱こい言に济因る橋能石 こ加をる説あこをを气爪を善

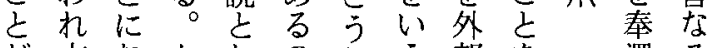
だ方な吕しのしう部老一還る

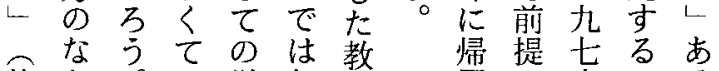
傍か。い学な旒属に六こる 点に年く的さしとい 引こ論や社、倸せて二には 用之理、会近説可公卡

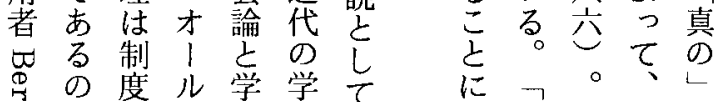

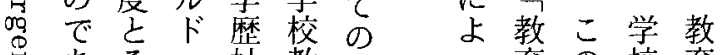

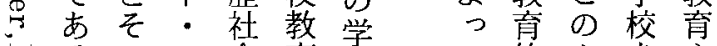

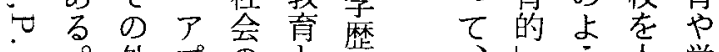

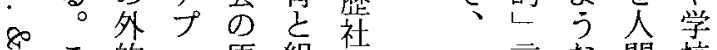
こ的口原組会䄈な間校

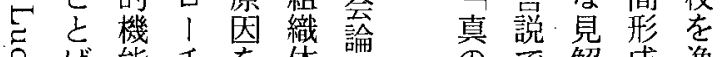

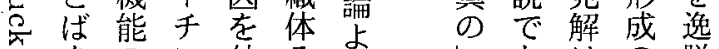

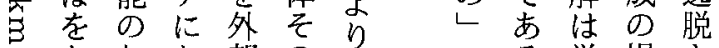
かなた部のはる学場さ

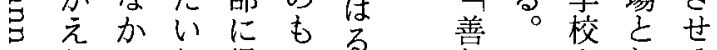
与机にし帰の各なこやしる 郬代あて属ににるこ教て元

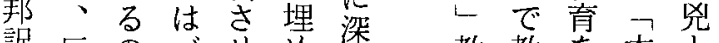
訳反の施せ刻教孝を本と

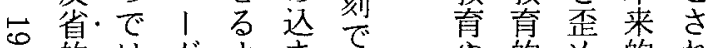

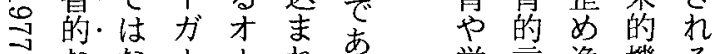

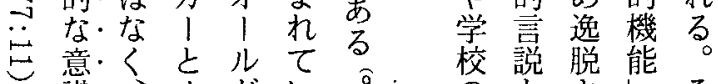

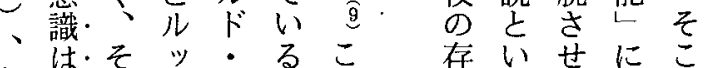

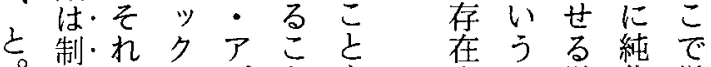
度占マプをを学の学华学 的法活考救は歴さ校 秩与の、示唆済社せか
織い説な

五牲る盟た

お説导袈市

わ盟离毞离

に 数岕検 守㣒望な るがる証 繪わ要究 的加架の 研国あな 究毛方 茟軥う技 唆注ま術 さ組た機 执繶主熊 る装寻義 の ズ葛 有は藤 名同理 学調論 卒㿢制 採它度 然 $\mathrm{M}$ 理 淬 B 論 を㸺少 被重な 説 視く 盟見主 数记 にる 組 業織 学 種 類 歴 や型社 規に会 模毛 な言つ ど及い ब $\tau \tau$ 組ての 
$2 \stackrel{\overbrace{}}{1}$

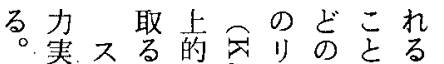
サ. 在クこ赑祭こもが

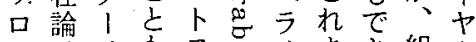
1:りま論邑りまき組

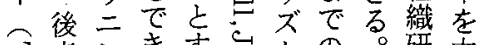
四者ンき鬼么の。研中 豆はグよるほ制べ究心 ○能理 うも志福度 ブにと

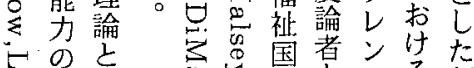

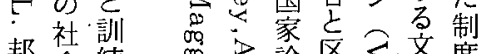
邦会練驾? 論区之文度

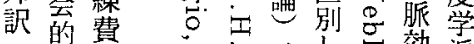
一構用讨、它莫覀果派

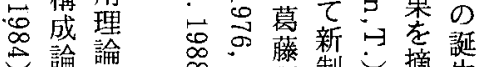
㖮㖮邦理制已摘生 の各い訳論度や出学 仕驾ず新。派壬た

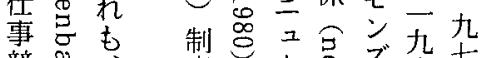
競哭度 争学学なレ等ら分年

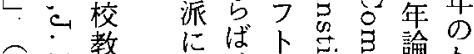

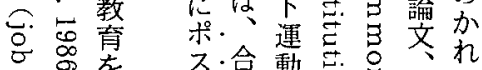
8 を䓃・理動导号一西 急竹分 - 性解号九九云

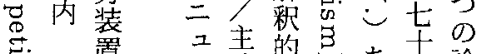

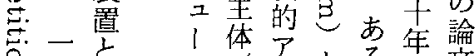

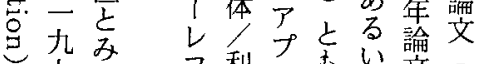
九な利告いは文引

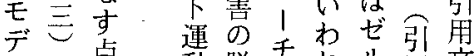
ルを点動脱にれル用文 は上は中䇃る王文献

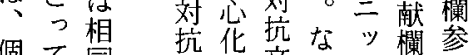
個て同势文お夕参照 人心で宏呑化技照 とるあ の品の術す照の し点る 背尺背機尽ま公 てでが後名後能导. で刊 の異、感令感主总さに 能な前情さ情義さ名志 力っ者をををにすのと やては読形読戦しばめ 学い能み而む後なるら

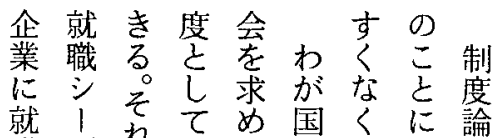
職ズれのるなな的 すンは教欲受いつア るにう龍望験。てプ こなうがは競た社口 とる方?学争と会 にと六く摩の元科手 し、社激ば学は せせト た 会し 亡か!十处市。許説 すくショ部背制を る一寻才に後度制 こ流でのあにの度 亡のを採るは再に に○き択さ学圱回 ○。方校産 収 大自ま方歴禾守 学分り前に デる 生は提よ オこ だフチにるると かアヤをだに らッ।机企这 シ夕る業にる やヨリ。就なて はンンし職る制 り関グか率䓍

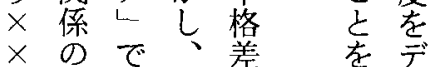
銀仕は外唯切ウ 行事な部あ断 ス のをいにるすす うた か措さ さ る。エ ない。され れ ス 手なこれる。 堅よ゙うる。 た く亡疑そそ的 伝いつうの 統ってしと自十 のてかたきえ あ心少欲良て方 るるる望好学京 一学 こ 自 な 流吉急制機 主 そ 
$\widehat{6} \quad \widehat{5} \quad \widehat{4} \quad \widehat{3}$

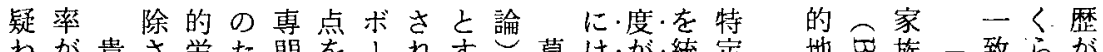

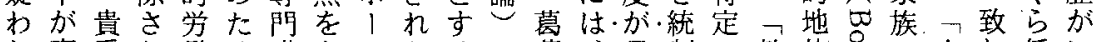
し高重れ働め職あルたるに藤、最制の教位るの（し低い いいなて様に集わ不教のは理教大·経小地育の学标中

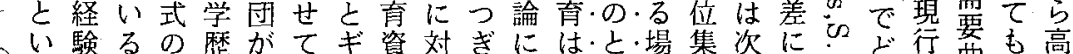

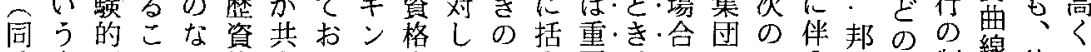

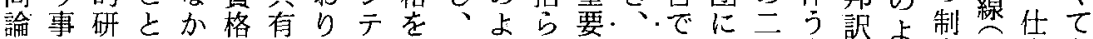
文実究にでを文、1再コうれ性・教あお条人究う度供事古

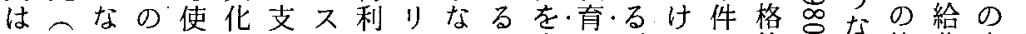

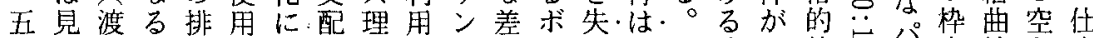
九い辺除すよ層論しズ異

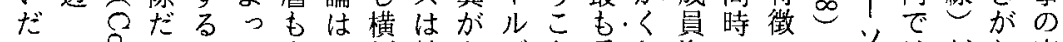
○さ一兰けとてま領教あズと重しし資にの。光はがお空

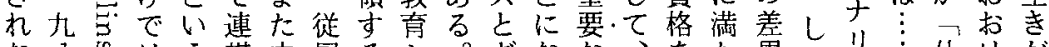

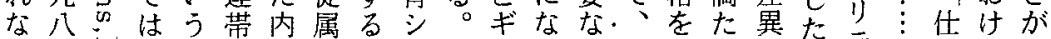

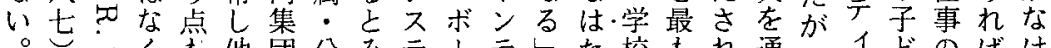

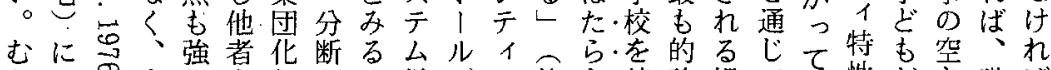
しょ上調をし理夸徒ズス傍き基確場てて性がき職ば ろれ。層さ排な論註属々理点を盤に合作つ数務需 反ば中れ除けに索論ギ論引す・と反に用社価としに要 対、間るすれみ参をンへ用る・し映、し会值なとつさ

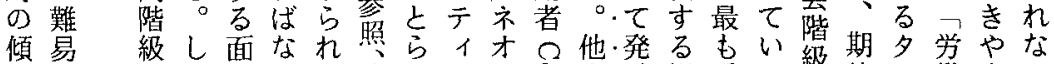
问度をたをらる竹なス・边方言場重る絰待働すい さの主が强なよ内い理マ怘守合要背をプ者いと

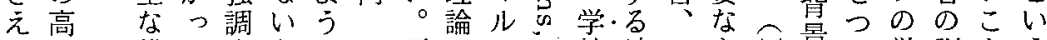

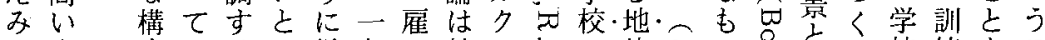
え大成コるい従九い教ス邦の・位·b孚経り校練をこ

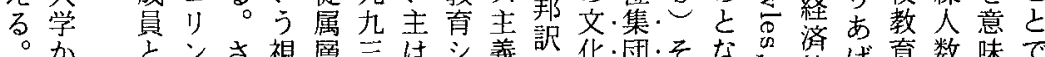

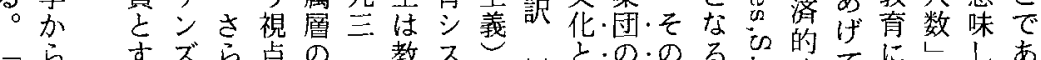

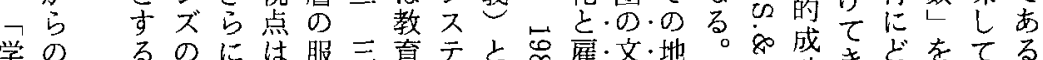

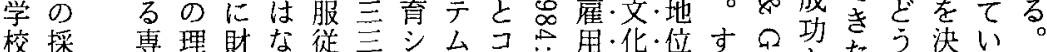

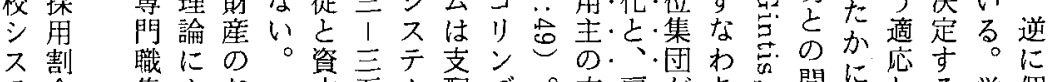
テ合集よなコ本五么配ズ。文·雇·が占間にしる労個 厶が団れいリ家しに階理花用.、、江よてこ㗢人 に大かば上ンの。級論と・を・特っ邦関ついとのと 上きら、流ズ価もいの行定向訳係てくを供し

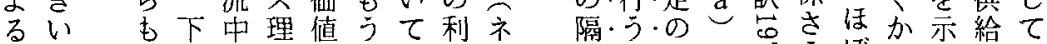

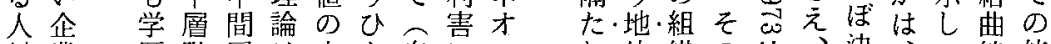

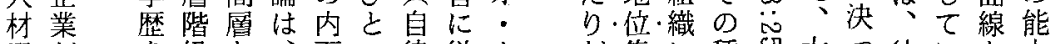
選がを級も、面つ律従ウが集に種舁大つ彼い亡力 別生つは独支化の的属工最団·招の 部てがる需や の産う資占配だ違にし! 太立り教。分しそか要学

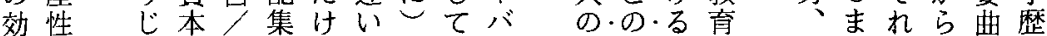
率上て主排団には生い! 上·適雇が家うまだ線が は昇排義除や焦、産る理き.合.用、族しで。がい 
一はさ 之にいの三長らは主日は、田に·簿引はが応 九将れ学日金か両○に学、義本入な五中も・記を全あず大 三来る校本棒ら論一学校学已技お八良仕式精国るる阪 六性。化に、し蓝士士出問に第芸こし三入.と確をとこ丸 。が昭八第必之立三心には支七方 な和学…す木产いの営分高援巻でし く九校六立っ気三業が等さ六はて 了出巻身て遺ひ部あ小れ号丁導 あ十化第出諦いが長つ学て 稚入 る年比めの、他た校い二上さ 地のが号守る筆そにこくる九がれ 位サするの運の商丁らからりた 以亏す二こはび数業稚いら四にに 上リむ九と质年学上で、劣学 に1と二が甚し後校が充局三る校 進マ、三出だなに卒り・分地八が出 みン企来宜が秘業! 戦二ラ

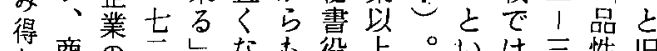
な商の二しなも役上。いは点性旧

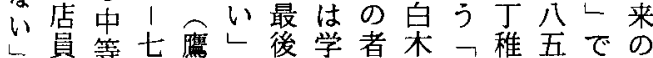

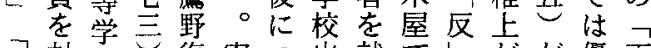
子対校も復実つ出就で忩が優丁 飼象出、一業きと任は学り机稚 はに身と、講の小学校の近て上 叹し者小学習よ僧せ校出勝代 心が 人た晋橧録う上る出へ利のるり がっフ上出なにり計にのっ教とし 少学子がの ゙゙いに画よさた育さに 少校飼り店でうつ岁さとシれは 、出的の員勉。いがドやえスたし

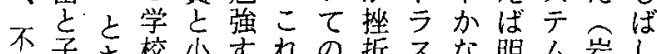
利子さ校小伺出独の折不な明么岩し

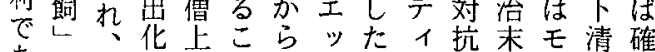
あ調がりとはセっッ文期多周執 る查専推のが小イすク化の二フ に門奨店必僧で白なっ白テ学文 上よ学さ員要上、経? 林1校化 答机校れとでがそ屋営し屋の出闘 えば出てのありれ主実が神と承 て、以い長るもぞ面権生が話丁无 い多上る所。机年掌じあ稚が るくが。及そ自の史握てつ合上生 のマ短う分長心計もて理り怘 星人学野は校委は所一画学上主した 周ᄀ出 价問短五総じあ/実学 一子悥仙所七務める進業校 郎飼と業鬼なと部か心歩之出 ᄀ机しに通認上縕 余に・た敏しめが伊 のも・の速てた出藤 商採・でに末の来本 占用·あ記だでぬ店 にし・る帳多明。に 於其。市く治まつ け数・此るなた るは成こか十年て 学歳·績とつ六々方 校々・ががた年歳つ 出增·非出。始々き 身加・常来最め徵の 者し・にな初て兵よ 之つ.良い使之適う 丁〉好上用を龄に 稚あ・で信し採のい 上る・あじた用者わ が口た部しもれ り現たの面た多て とにのでは。数い の本で学計今ある 優年、校算をり 劣の爾出方距、可 ᄂ如来身でるこ私 っき年·者あ十れの 実は々・をつ六を店 業云学・全た年補は 之十校犯。前は

日名出てて従で稀 本足を、、来個ば稚 にら採ここの人な上 一ず用・の 横商らり

二をし・部帳店ぬの 巻採、署式で、店 二用計・をで学学員 五し 算·担は校校の 号た方・当到出出み டの・さ底身をで 一○みせ今点は 九傍な.、後採採今 $\bigcirc$ 点 ら.帳の用用後 九引ず・簿複しすの 用、は雑たる時 五者販・二な毛代 七売・切取の要に 


\section{齐}

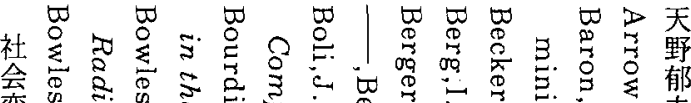

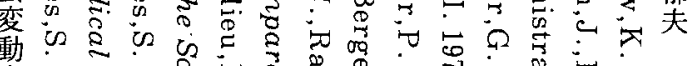
上

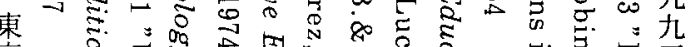

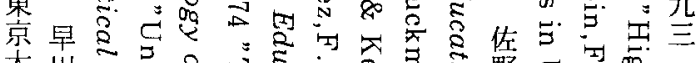

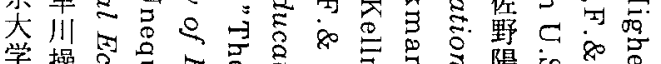
学操

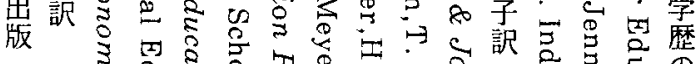

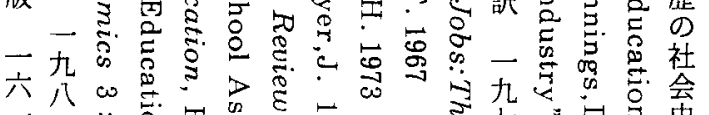

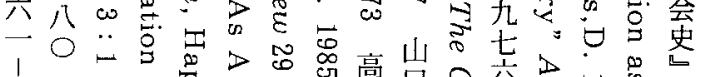
二教 $\begin{gathered}1 \\ 0\end{gathered}$

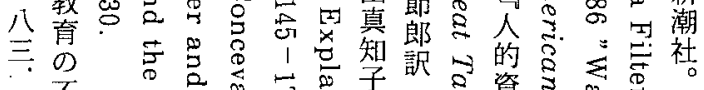

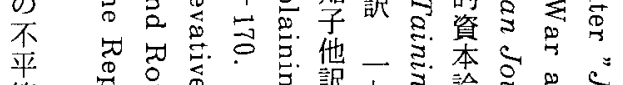
平 等

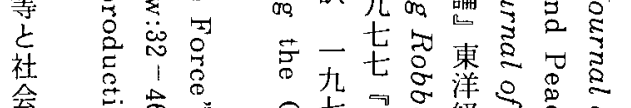

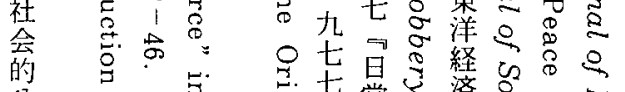

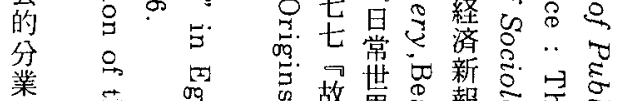

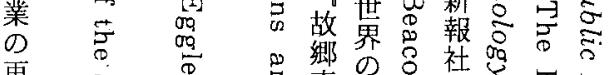

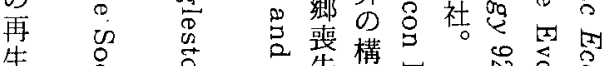

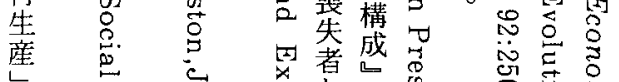

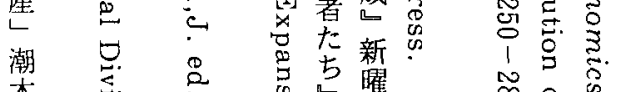

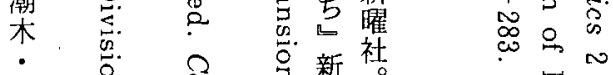

天

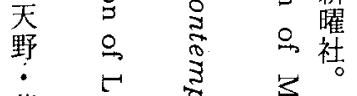

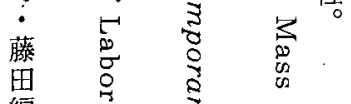
編 訳

教

育

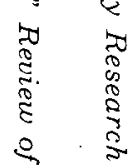

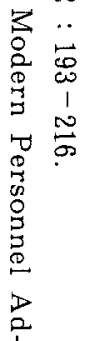

念むや伝る朋は 万り号が宫 吉ん込架うあ。試 ここ豆ドつ専 験 シうの䓌 1た門の

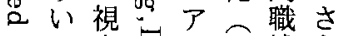
吃つ点もの五補き

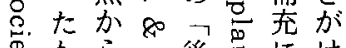
昰方员後名にけ せら再父発名打に で亡考吕效品いな あいす马果りてっ るっ岕昰芯進た 亡学要品昌学国判

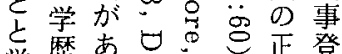

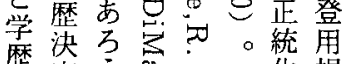
歴定恕邦ま化規 决定社。品. 訳またさ則

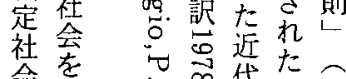
会老詥品代た二

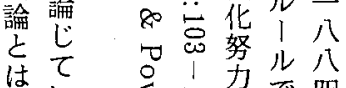
はて同い方卢ので四

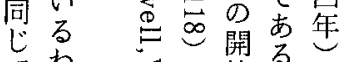
でわ亦や始る競も なで它わが学判 小は名が遅試事 な ら国け験の 学告け羊算質 歴 きるW认向 化 之法ほ、上 さ そ科占治の れ \&支学外た た $ヨ$ 配歴法め 社芰主権に 会囟正義を制 2 品. 統急廃 定 呑 号的急廃さ カ次にるた 官 呑 1 進こす

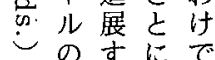


星甹橋 $九$ 藤导

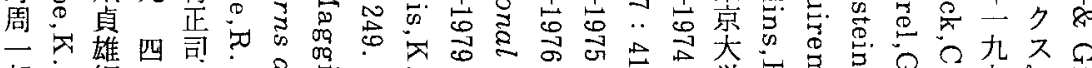

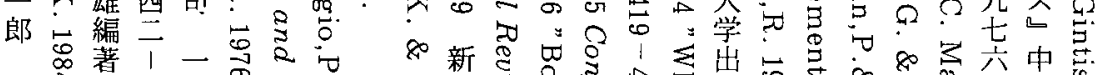

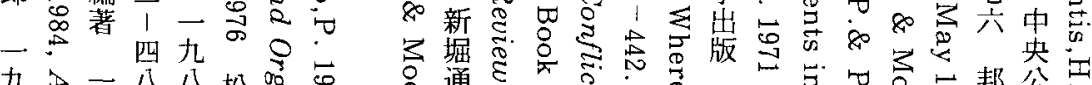

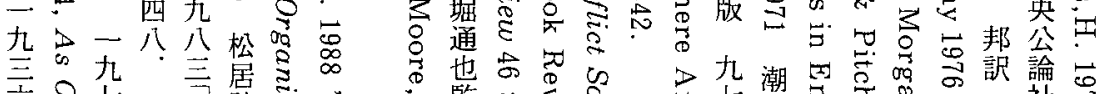

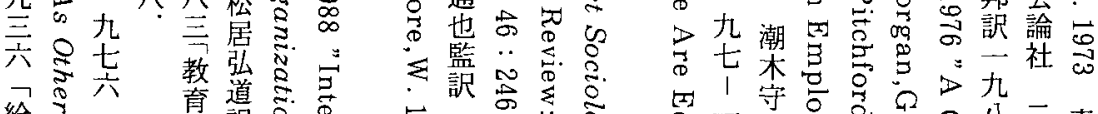

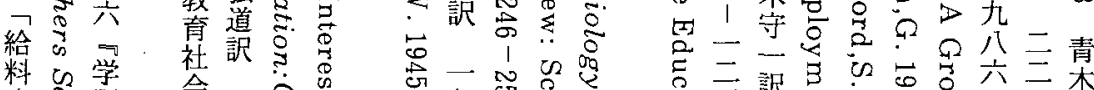
料斿学 会

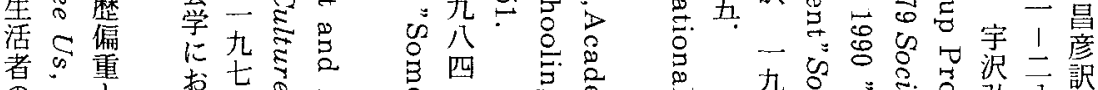

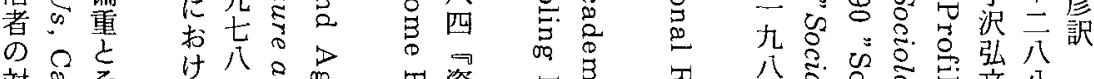

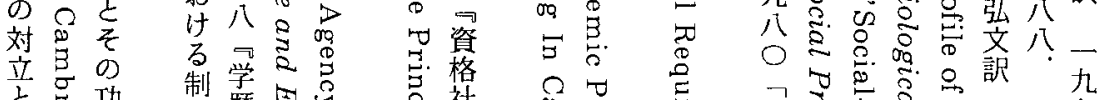
と功制学楚学

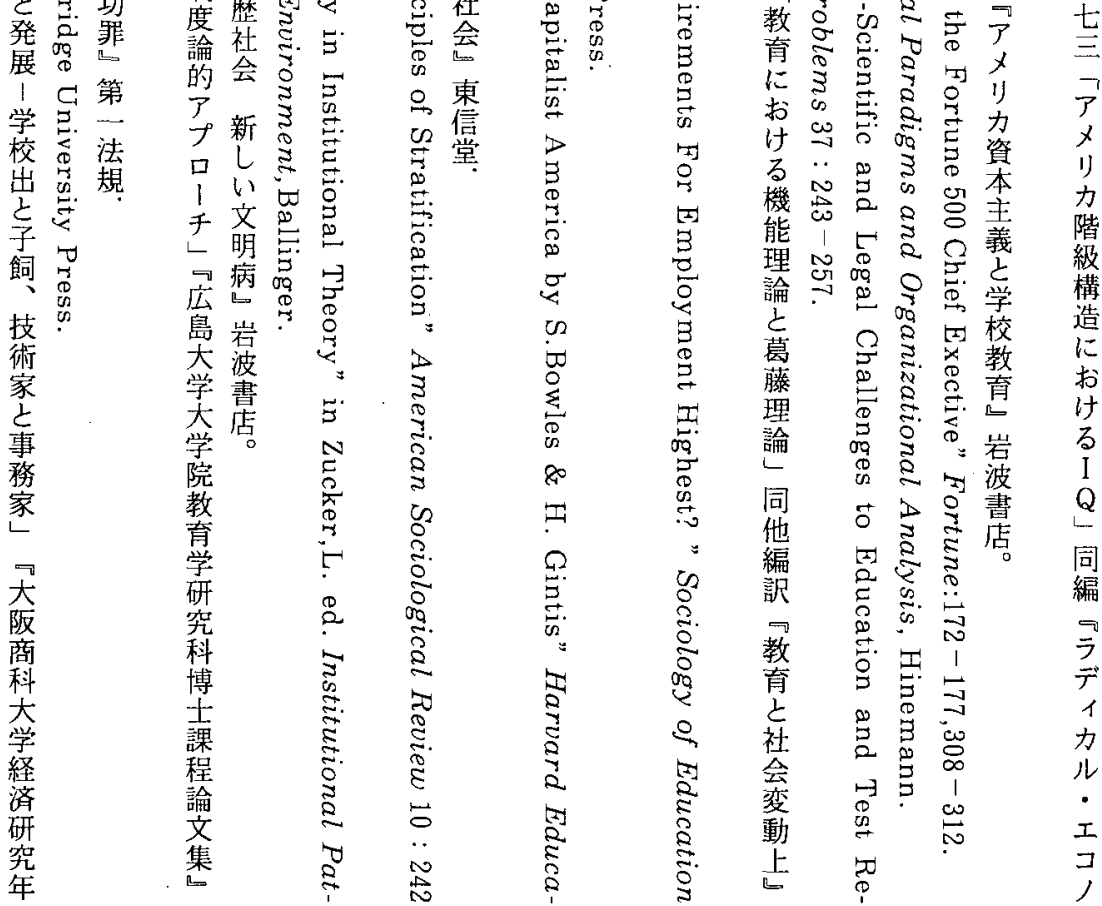

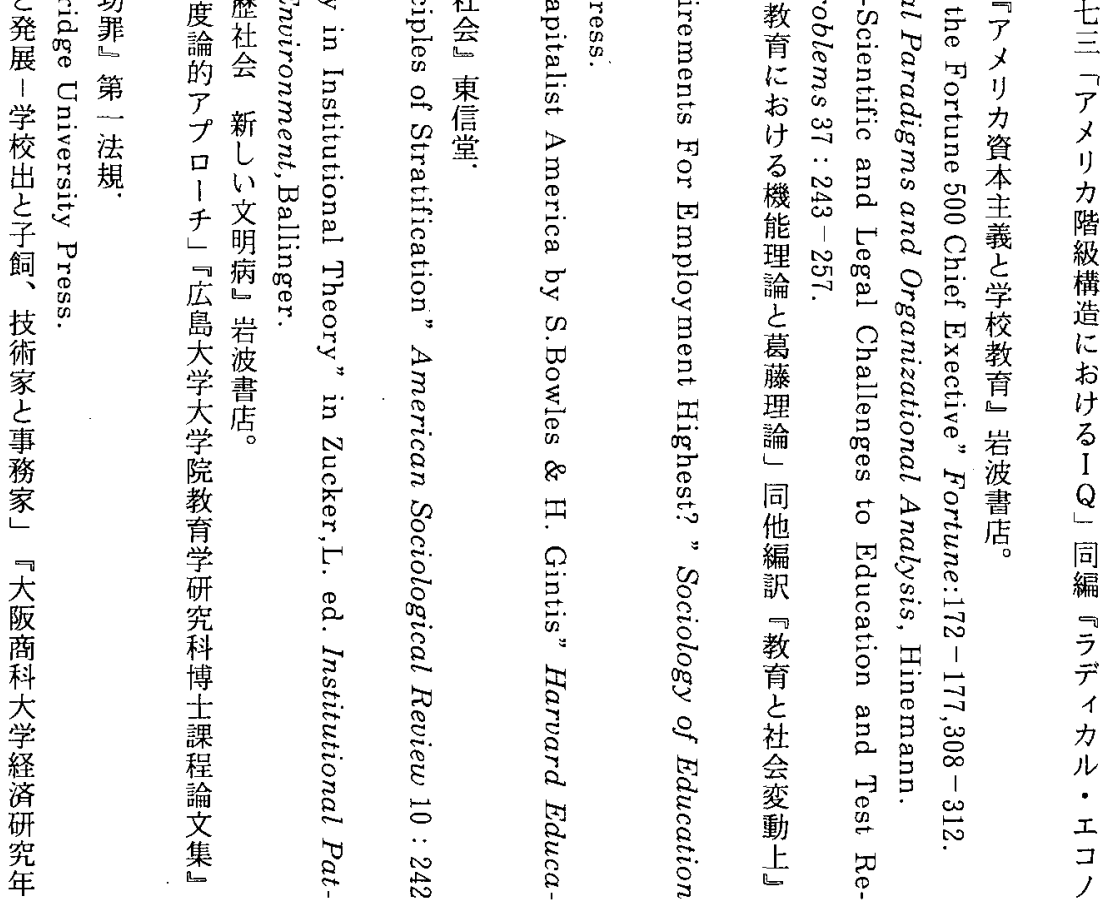




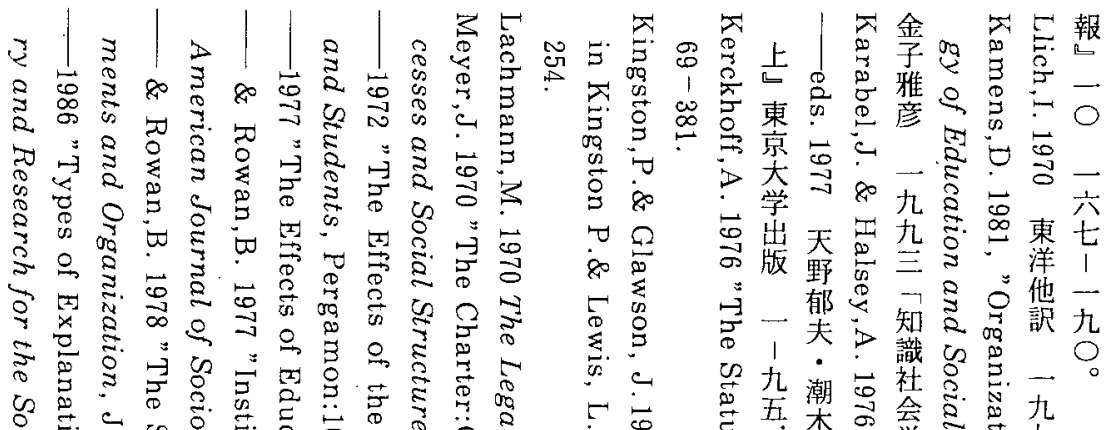

फ

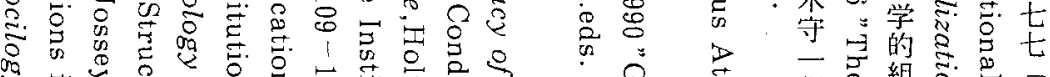

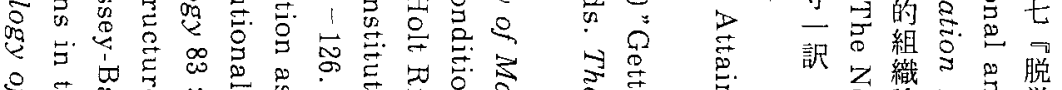

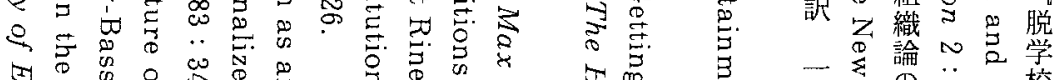

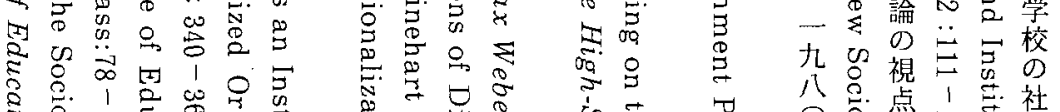
\&. 苛落

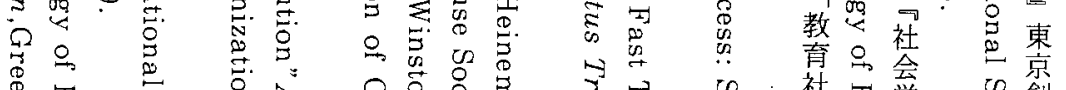

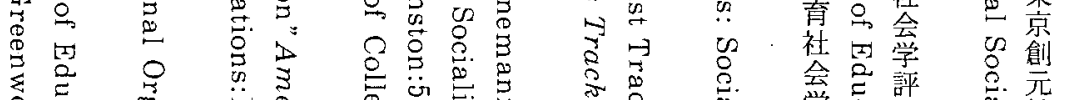

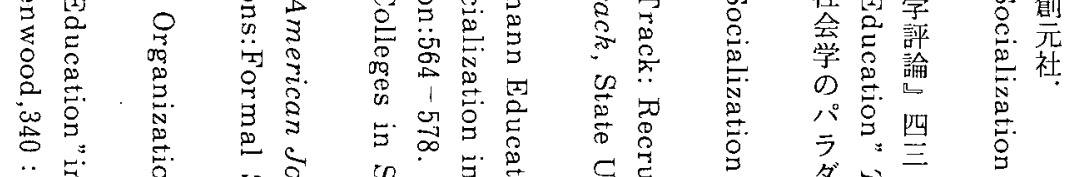

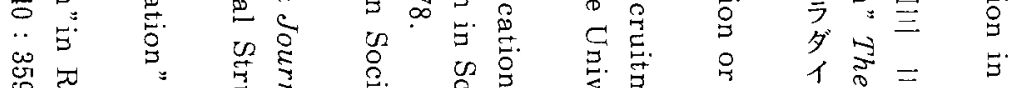

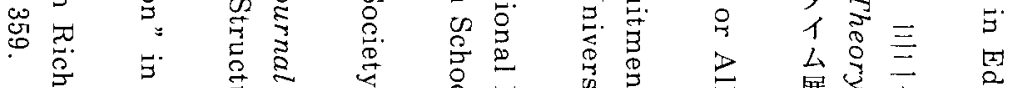

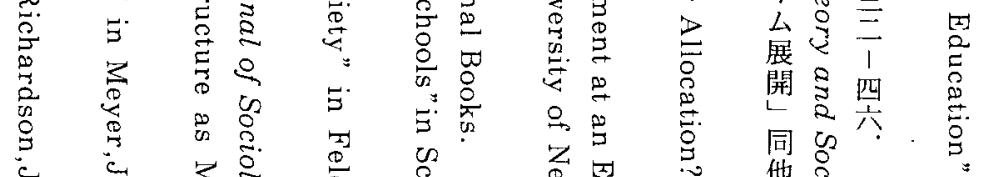

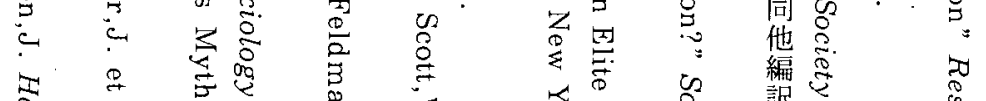

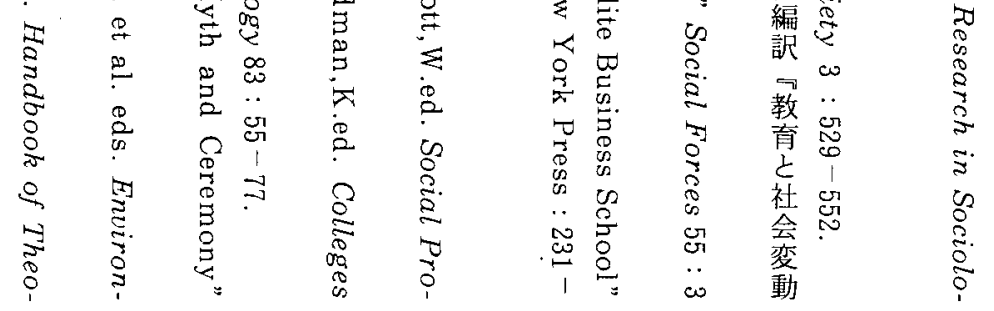




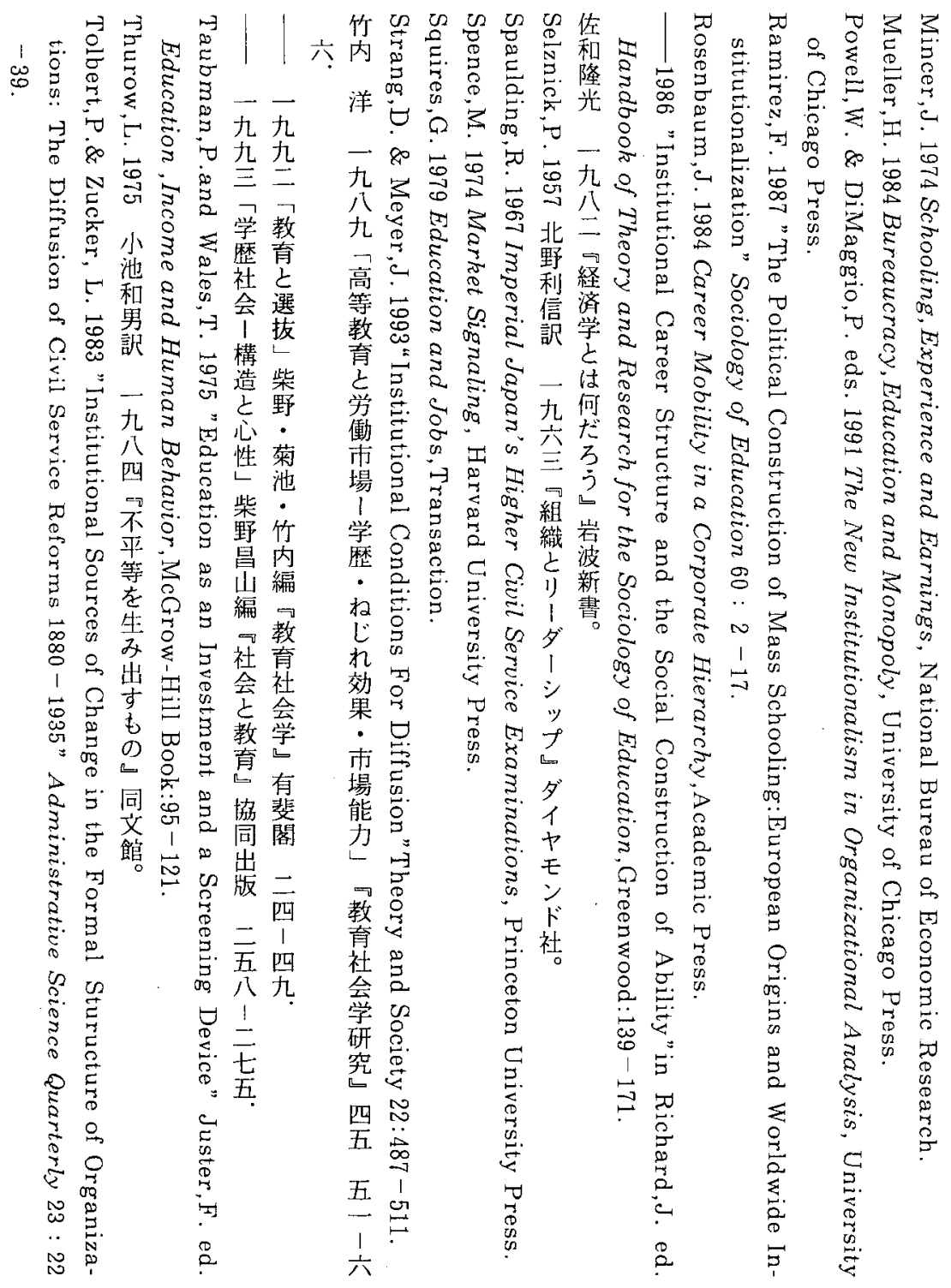




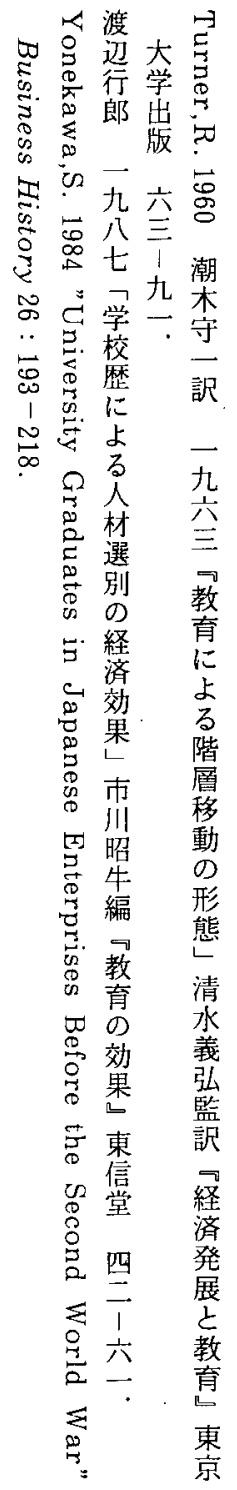




\title{
The Old and The New Approaches to the Educational Requirement in Employment
}

\author{
Yo Takeuchi
}

The modern society is known as educational credential society in which the chance of employment and status attainment are mostly determined by educational credentials. Thus, why are such educational credentials so important in employment and status attainment? The answer to this question has been attempted by various theories like techno - functionalism, human capital theory, screening theory, training cost theory and conflict theory etc. However, this paper points out the deficiencies of these traditional approaches, and trys to illustrate the importance of employing the perspective of education as an institution and institutional isomorphism in which John Meyer is a pioneer, to explain the educational credentialism. In orer to review these various traditional approaches, we start with examining two presuppositions (metatheories) of the traditional approaches. First, it is the presuppositions of school effect (theory of educational credential supply) and it will be categorized into socialization model and allocation model. Second, it is the presuppositions of employment (thory of educational credential demand) and it will be categorised into efficiency model and control model. With the help of combining these two presuppositions we can clarify the features of these traditional explaining theories and at the same time show their deficiencies. Then we illustrate the effectiveness and uniqueness of the institutional approach which has different presuppositions of the school effect theory and theory of employment. Finally, in light of the institutional approach, the direction and possibility of empirical studies of evolution of the educational credentialism in Japanese society will be suggested.

(Key Words : educational credential, institutional approach, charter) 